\title{
BEACH RESPONSE TO THE REDINGTON SHORES FLORIDA BREAKWATER
}

\author{
by \\ Yen-Hsi Chu \\ Coastal Engineering Research Center \\ DEPARTMENT OF THE ARMY \\ Waterways Experiment Station, Corps of Engineers \\ 3909 Halls Ferry Road, Vicksburg, Mississippi 39180-6199 \\ and \\ Thomas Martin \\ DEPARTMENT OF THE ARMY \\ US Army Engineer District, Jacksonville \\ 400 West Bay Street, Jacksonville, Florida 32232-0019

\section{CERC LIBRARY}
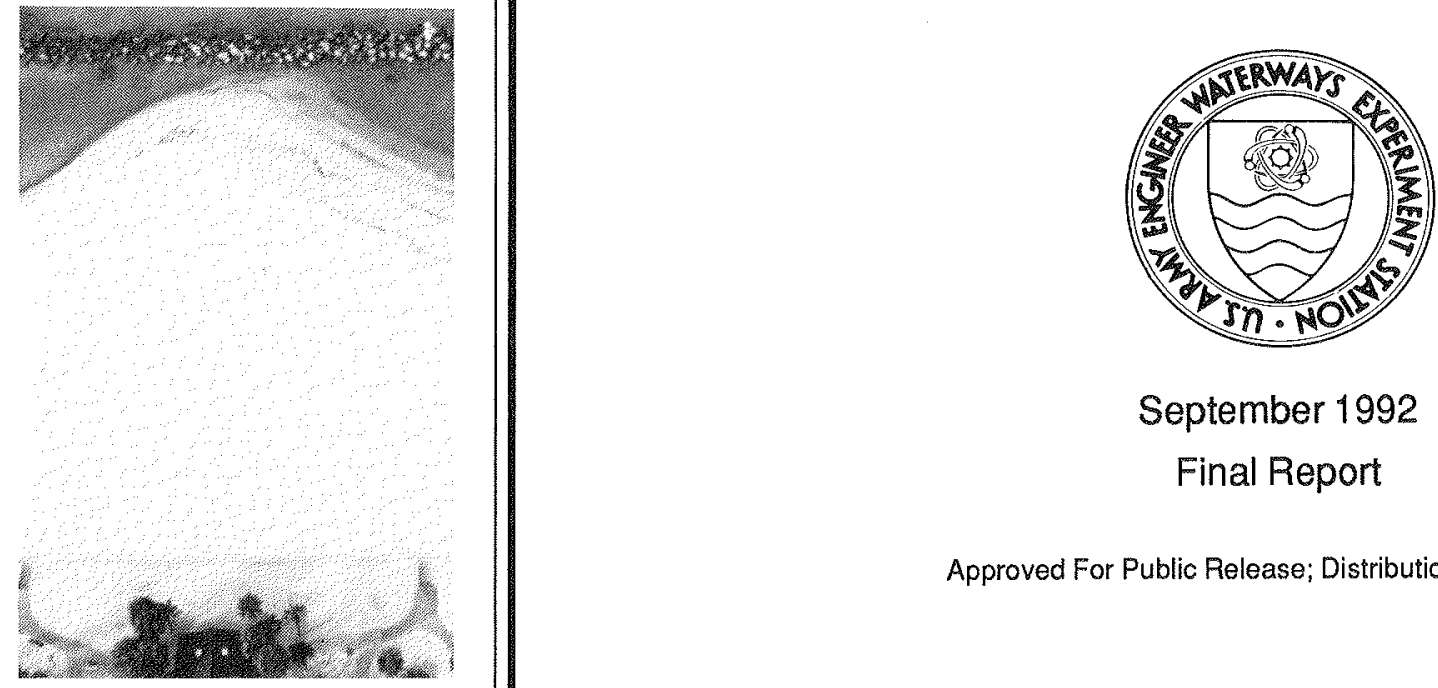

September 1992

Final Report

Approved For Public Release; Distribution Is Unlimited

Prepared for DEPARTMENT OF THE ARMY

US Army Corps of Engineers

Washington, DC 20314-1000

Under Civil Works Research Work Unit 32535 
Destroy this report when no longer needed. Do not return it to the originator.

The findings in this report are not to be construed as an official Department of the Army position unless so designated by other authorized documents.

The contents of this report are not to be used for advertising, publication, or promotional purposes. Citation of trade names does not constitute an official endorsement or approval of the use of such commercial products. 


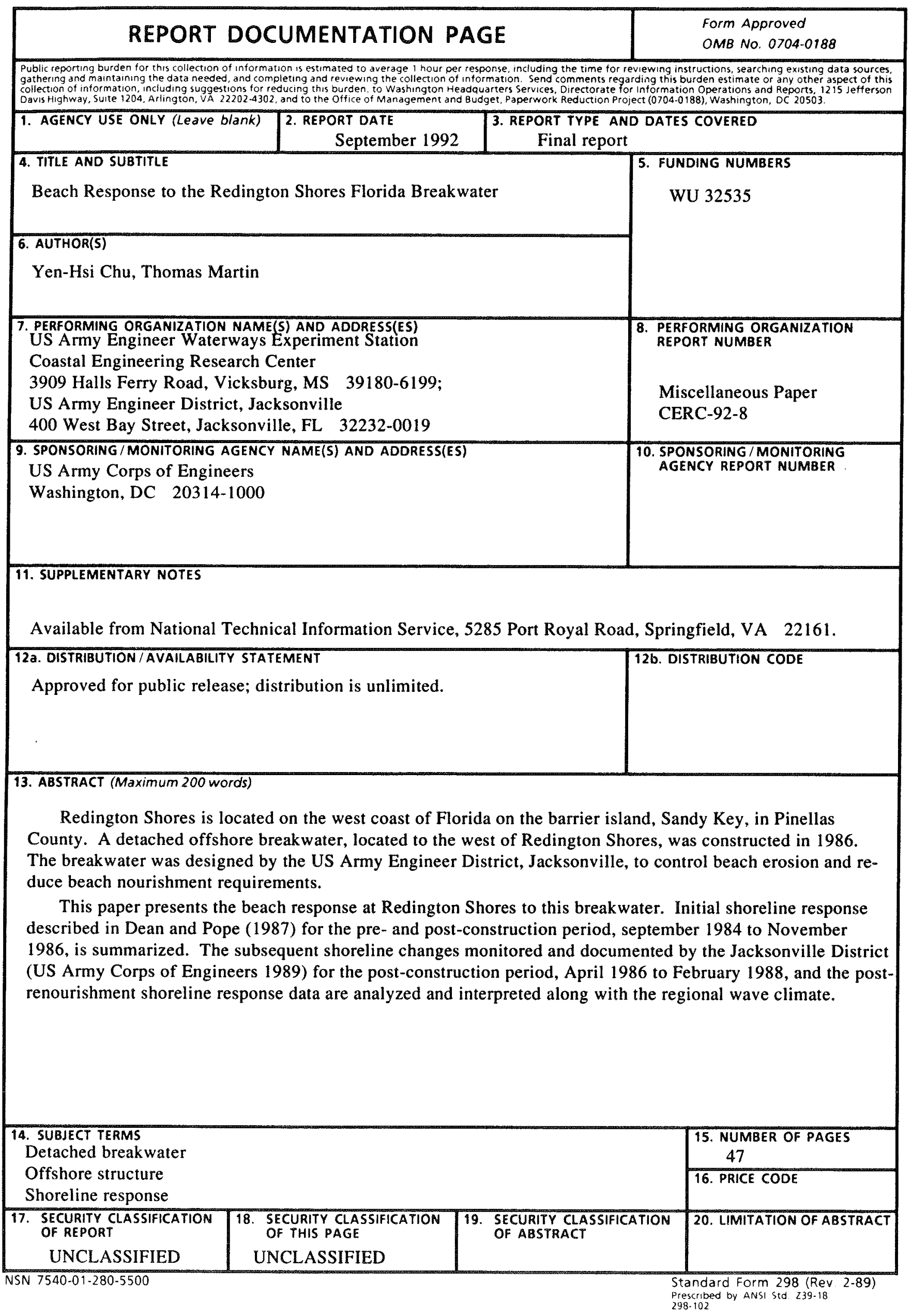


The study summarized in this report was authorized by Headquarters, US Army Corps of Engineers, and performed as a part of Civil Works Research and Development Work Unit 32535, "Engineering Performance of Coastal Structures." Mr. J. H. Lockhart, Jr., was Technical Monitor. Funds were provided through the Coastal Structures and Evaluation Branch (CS\&E), of the Coastal Engineering Research Center (CERC), US Army Engineer Waterways Experiment Station (WES), Vicksburg, MS.

Work was performed under the general supervisory direction of Ms. Joan Pope, Chief, CS\&E; Mr. Thomas W. Richardson, Chief, Engineering Development Division, CERC; Dr. C. Linwood Vincent, Program Manager, CERC; Mr. Charles C. Calhoun, Jr., Assistant Director, CERC; and Dr. James R. Houston, Director, CERC.

This report was prepared by Dr. Yen-Hsi Chu, Chief, Engineering Applications Unit (EAU), CS\&E; and Mr. Thomas Martin, Jacksonville District. Mr. Thomas Denes, formerly of CERC, and Mr. Marcel Pope, formerly of CERC and the Jacksonville District, also contributed to the preparation of this report. Ms. Lynn Bessonette, formerly of CERC, prepared most of the figures in this report. Mr. James E. Clausner and Ms. Julie Dean Rosati, CERC, served as technical reviewers.

At the time of preparation of this report, Director of WES was Dr. Robert W. Whalin. Commander and Deputy Director was COL Leonard G. Hasse11, EN. 
CONTENTS

PREFACE . . . . . . . . . . . . . . . . . . . . . . . . . . . . . . . . . . 1

CONVERSION FACTORS, NON-SI TO SI (METRIC) UNITS OF MEASUREMENT . . . . . . 4

PART I: INTRODUCTION . . . . . . . . . . . . . . . . . . . . . . . 5

Background . . . . . . . . . . . . . . . . . . . . . . . . . 5

Site Description . . . . . . . . . . . . . . . . . . . . . . . . . 5

Breakwater Construction and Beach Nourishment Activities . . . . . 7

Monitoring Redington Beach . . . . . . . . . . . . . . . . . . . . 10

PART II: SURVEY RESULTS AND DISCUSSIONS . . . . . . . . . . . . . . . . . . . . 16

Initial Shoreline Response . . . . . . . . . . . . . . . . . . . . 16

Post-Construction Shoreline Response . . . . . . . . . . . . . . . 19

Post-Renourishment Shoreline Response . . . . . . . . . . . . . . . 27

PART III: SUMMARY AND CONCLUSIONS . . . . . . . . . . . . . . . . . . . . . . . . 29

REFERENCES . . . . . . . . . . . . . . . . . . . . . . . . . . . . . . . . 31

APPENDIX A: AERIAL PHOTOGRAPHS OF REDINGTON SHORES BREAKWATER . . . . . . A1 
№.

$\underline{\text { Page }}$

1

2

3

4

5

6

7

8

9

10

11

12

No.

1

2

1

Project location map . . . . . . . . . . . . . . . . . . . . 6

Winds for southwestern Florida. . . . . . . . . . . . . . . 9

WIS hindcast wave rose for the Redington Shores

vicinity . . . . . . . . . . . . . . . . . . . . . . . . . . 11

Plan view and cross section of Redington Shores

breakwater. . . . . . . . . . . . . . . . . . . . . . 12

Activities associated with Redington Breakwater

(1984-1989) . . . . . . . . . . . . . . . . . . . 13

Profile line locations at Redington Shores . . . . . . . . . 14

Compilation of shorelines digitized from aerial

photographs (after Dean and Pope 1987) . . . . . . . . . . . 16

Contour changes . . . . . . . . . . . . . . . . . . . . . . 20

Redington Shores breakwater volume changes . . . . . . . . . 24

Contour changes . . . . . . . . . . . . . . . . . . . . . . 25

Redington Shores breakwater volume changes . . . . . . . . . 26

Contour changes . . . . . . . . . . . . . . . . . . . . . . 28

\section{LIST OF TABLES}

No. of Seasonal Occurrences of Wind Directions and

Average Monthly Wind Speeds in the Vicinity of

Redington Shores.. . . . . . . . . . . . . . . . . . . . . 8

Volume Changes from Bathymetric Surveys (Dean and

Pope 1987) . . . . . . . . . . . . . . . . . . . . . . . . . 18

Redington Shores Breakwater Volumetric Changes. . . . . . 21 
CONVERSION FACTORS, NON-SI TO SI (METRIC) UNITS OF MEASUREMENT

Non-SI units of measurement used in this report can be converted to SI (metric) units as follows:

Multiply

cubic yards

feet

knots (international)

miles (US Statute)
By

0.0283168

0.0348

0.5144444

1.609347
To Obtain

cubic meters

meters

meters pre second

kilometers 
BEACH RESPONSE TO THE REDINGTON SHORES, FLORIDA BREAKWATER

PART I: INTRODUCTION

\section{Background}

1. This report documents the beach response at Redington Shores, Florida to a detached offshore breakwater constructed in 1986 . This report is intended to be a review of existing literature. This report summarizes the initial shoreline response described in Dean and Pope (1987) for the pre- and post-construction period, September 1984 to November 1986 , the subsequent shoreline response described by the Jacksonville District (U.S. Army Corps of Engineers 1989) for the post-construction period, April 1986 to February 1988, and the post-renourishment shoreline response partially described by the Jacksonville District (U.S. Army Corps of Engineers 1989) for the period, February 1988 to July 1989

2. Detached breakwaters are structures situated offshore and generally parallel to the shore. They are intended to protect the adjacent shore from erosion by attenuating incoming wave energy. Some wave energy does exist in the lee of the breakwater but it is insufficient to erode the beach. Some sediment may deposit in the lee of the breakwater. High energy waves and currents transport sediment into the quiescent environment to the lee of the breakwater, where the material settles out. Dean and Pope (1987) suggest that if the breakwater attenuates too much wave energy, sediment may eventually fill in the area in the lee of the breakwater and form a tombolo. The breakwater-tombolo system may then act as a groin disrupting the alongshore sediment transport processes in the area. In an optimum design, sediment is transported past the breakwater and the beach remains wide and detached from the structure (Dean and Pope 1987).

\section{Site Description}

3. Redington Shores is located on the west coast of Florida on the narrow arc-shaped barrier island, Sand Key, in Pinellas County (Figure 1). The Redington Shores breakwater is situated to the west of the Redington 


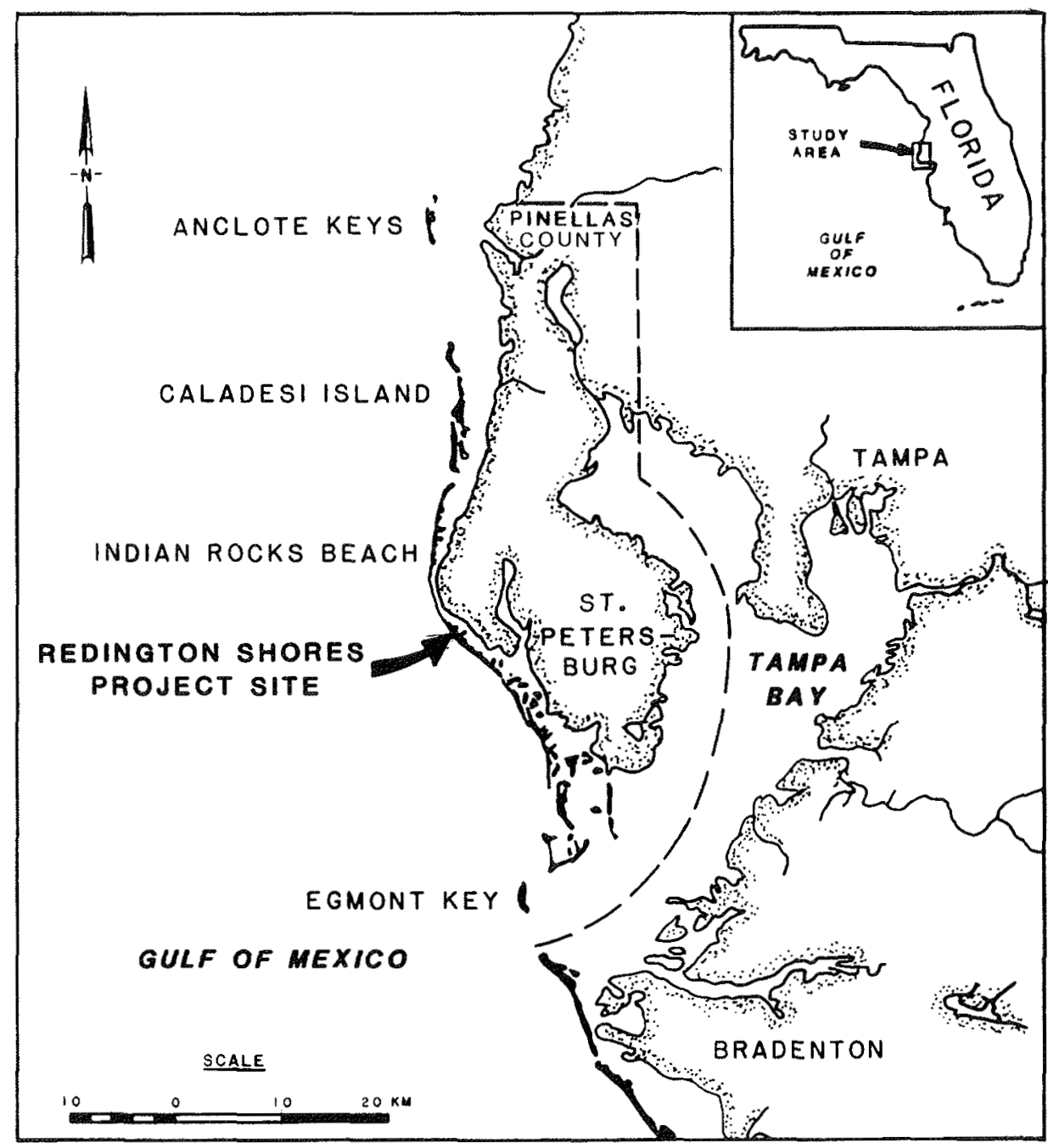

Figure 1. Project location map

Shores beach, approximately 6 miles* north of John's Pass and 8 miles south of Clearwater Pass. The breakwater is located $340 \mathrm{ft}$ from the existing seawall at the Redington Shores Beach Access, a Pinellas County park facility. The breakwater was designed by the U.S. Army Engineer District, Jacksonville to control beach erosion and reduce beach nourishment requirements. It was originally designed as an offshore detached rubble-mound structure. Since its completion, the spit in the lee of the breakwater has grown several hundred feet and is attached to the structure during low tide forming a tombolo.

* A table of factors for converting non-SI units of measurement to SI (metric) units $i$ presented on page 3 . 
4. Indian Rocks Beach, the most westerly point on Sand Key, forms a headland for the barrier island. The shoreline orientation and the shoreface gradient at Indian Rocks Beach create a nodal point for littoral transport (Dean and Pope 1987). North of Indian Rocks Beach, littoral transport is northerly, and south of it, transport is southerly. Because of the lack of littoral sand in the Gulf of Mexico, the center portion of Sand Key has been experiencing severe beach erosion. Before the breakwater was constructed, the Redington Shores beach had a minimal beach width that varied from $0 \mathrm{ft}$ to approximately $50 \mathrm{ft}$ at its widest section.

5. The west central coast of Florida is characterized as a low energy coast. Average yearly waves range from $0.2-1.0 \mathrm{ft}$ in height with a period from 2 - $4 \mathrm{sec}$ (Davis, Hine, and Belknap 1985). The mean tide range is $1.2 \mathrm{ft}$ and the spring tide range is $2.3 \mathrm{ft}$. Minor storm systems usually generate wave heights averaging from $1.6-2.0 \mathrm{ft}$ with periods of about $5 \mathrm{sec}$.

6. Because reliable site-specific directional wave data are lacking, the best available description of the regional wave climate is generated from wind data. Table 1 is the summary of monthly wind directions from the Wave Information Study (WIS) database (Hubertz and Brooks 1989) for the Redington Beach area. In spite of the fact that most of the wind energy has an offshore component ( 45 - $135 \mathrm{deg}$ ), distinct bimodal seasonal variations can be detected for the onshore winds. During the fall and winter, onshore winds are mostly from northerly directions (315 - 0 deg) whereas, during the spring and summer months, onshore winds are mostly from southerly directions (225-270 deg). Stronger winds usually occur during the winter and weaker winds during the summer. The WIS hindcast wind data are consistent with the wind data reported by Rosen (1976) for the region (Figures $2 \mathrm{a}$ and $2 \mathrm{~b}$ ). The seasonality of the wind/wave climate can significantly influence longshore sediment transport and cause local reversals in transport direction. Figure 3 is the wave rose based on the WIS hindcast data (Hubertz and Brooks 1989).

\section{Breakwater Construction and Beach Nourishment Activities}

7. The Redington Shores breakwater was constructed by the U.S. Army Engineer District, Jacksonville, between December 1985 and January 1986. 
Table 1

No. of Seasonal Occurrences of Wind Directions and Average Monthly Wind Speeds in the Vicinity of Redington Shores

\begin{tabular}{|c|c|c|c|c|c|c|c|c|c|c|}
\hline \multirow[b]{2}{*}{ Season } & \multirow[b]{2}{*}{ Month } & \multicolumn{8}{|c|}{$\begin{array}{l}\text { Number of Occurrences } \\
\text { Direction (degrees from north) }\end{array}$} & \multirow{2}{*}{$\begin{array}{l}\text { Average } \\
\text { Wind Speed } \\
\text { (Knots) }\end{array}$} \\
\hline & & 0 & 45 & 90 & $\underline{135}$ & $\underline{180}$ & 225 & 270 & $\underline{315}$ & \\
\hline & $\mathrm{DEC}$ & 506 & 830 & 1417 & 551 & 374 & 311 & 404 & 567 & 13.7 \\
\hline \multirow[t]{2}{*}{ Winter } & JAN & 499 & 799 & 1273 & 558 & 356 & 444 & 457 & 574 & 13.8 \\
\hline & FEB & 436 & 585 & 874 & 582 & 464 & 429 & 501 & 649 & 13.8 \\
\hline \multirow[t]{2}{*}{ Total (8) } & & 10 & 15 & 25 & 12 & 8 & 8 & 9 & 12 & \\
\hline & MAR & 416 & 608 & 915 & 805 & 602 & 432 & 606 & 576 & 13.0 \\
\hline \multirow[t]{2}{*}{ Spring } & APR & 321 & 476 & 1220 & 812 & 544 & 490 & 537 & 400 & 12.1 \\
\hline & MAY & 233 & 608 & 1461 & 681 & 379 & 525 & 760 & 313 & 9.6 \\
\hline \multirow[t]{2}{*}{ Total (8) } & & 7 & 11 & 24 & 16 & 10 & 10 & 13 & 9 & \\
\hline & JUN & 148 & 550 & 1287 & 643 & 503 & 844 & 648 & 177 & 9.2 \\
\hline \multirow[t]{2}{*}{ Summer } & JUL & 61 & 223 & 1141 & 764 & 698 & 1021 & 954 & 98 & 9.4 \\
\hline & AUG & 128 & 475 & 1569 & 667 & 416 & 760 & 722 & 223 & 11.0 \\
\hline \multirow[t]{2}{*}{ Total (8) } & & 2 & 8 & 27 & 14 & 11 & 18 & 16 & 3 & \\
\hline & SEP & 152 & 1285 & 1898 & 480 & 175 & 265 & 358 & 187 & 13.3 \\
\hline \multirow[t]{2}{*}{ Fal1 } & $\mathrm{OCT}$ & 534 & 1505 & 1705 & 252 & 138 & 171 & 271 & 384 & 13.6 \\
\hline & NOV & 616 & 1056 & 1469 & 395 & 188 & 247 & 366 & 463 & 13.7 \\
\hline Total (8) & & 9 & 26 & 35 & 8 & 3 & 5 & 7 & 7 & \\
\hline
\end{tabular}




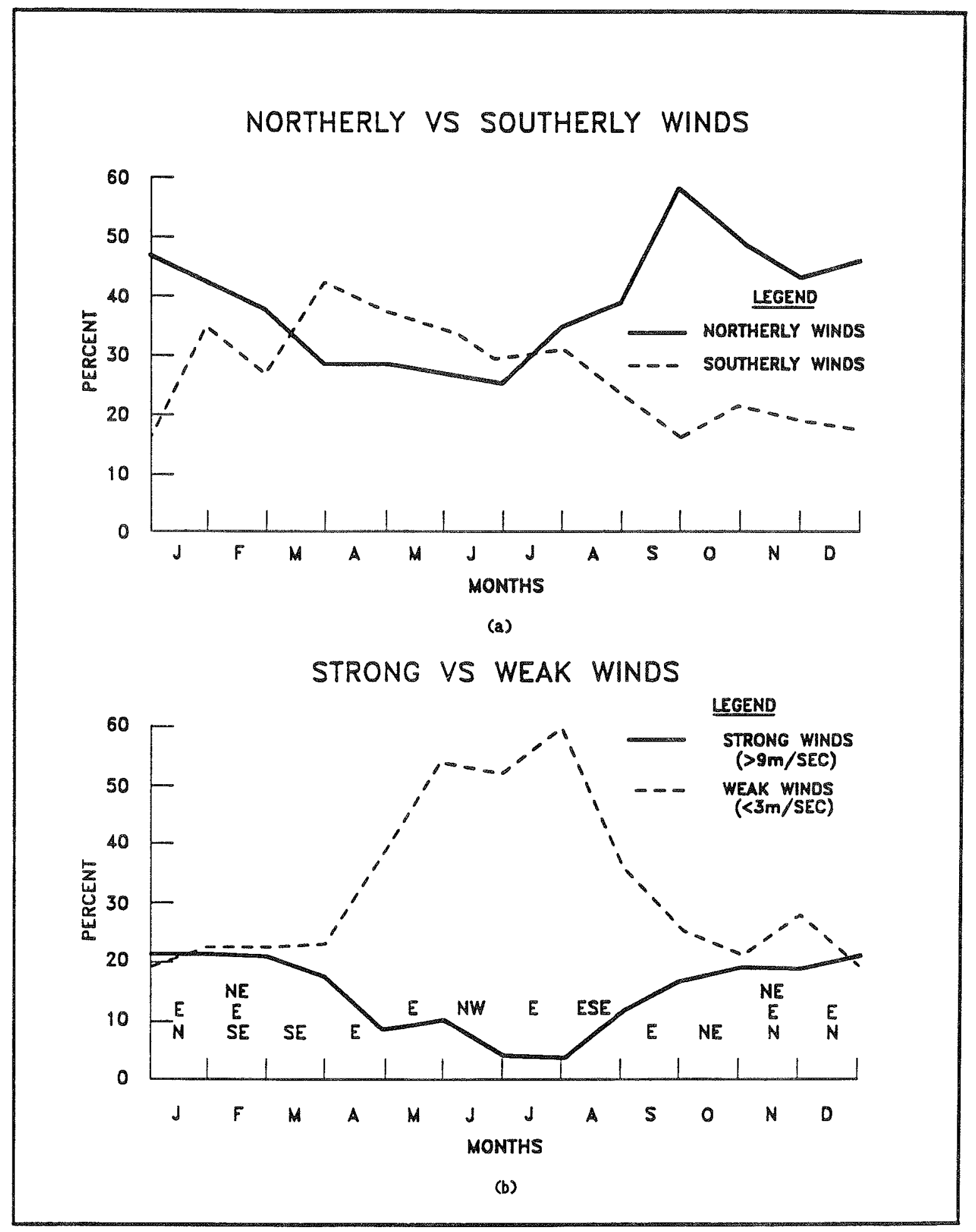

Figure 2. Winds for southwestern Florida
a) Directions
b) Strengths

(After Rosen 1976) 
Figure 4 shows a plan view of the breakwater. The first $260 \mathrm{ft}$ of the breakwater is parallel to the face of the seawall. The southern $90 \mathrm{ft}$ is a dogleg to the south at $45 \mathrm{deg}$ to the axis of the main trunk of the structure. Figure 4 also shows the design cross section of the rubble-mound structure. The crest elevation of $1.5 \mathrm{ft}$ above Mean Low Water (MLW) was selected to permit an average of 50 percent wave energy transmission (Dean and Pope 1987). The low-crested design was intended to facilitate longshore sediment transport during higher tide levels and storm events.

8. Immediately upon completion of construction, 30,000 cu yd of recently dredged material was placed in front of the existing seawall directly across from the breakwater. This material was native to the region and of similar characteristics to the existing sediment at Redington Beach.

9. In August 1988, Redington Shores beach was renourished. Approximately 380,000 cu yd of material was placed in most of the Redington Shores breakwater monitoring area. The material consisted of fine grey sand with some shell fragments and clay. Along with the renourishment, 38 stones were removed from the breakwater to lower the crest elevation from $1.5 \mathrm{ft}$ to $0.5 \mathrm{ft}$ above MLW. In theory this action would allow more wave energy to enter the lee of the breakwater and release sediment trapped in the tombolo to the downdrift beaches.

\section{Monitoring Redington Beach}

10. The Jacksonville District performed a number of surveys prior and subsequent to the construction of the Redington Shores breakwater. Figure 5 shows the chronological sequence of monitoring events associated with the breakwater. A pre-construction bathymetric survey was performed in September 1984. After completion of the breakwater in January 1986, a program was implemented by the Jacksonville District to monitor the beach response to the breakwater and to assess the effectiveness of the structure for beach erosion control. The monitoring program consists of nearshore bathymetric surveys and will continue for a minimum of five years. The survey area originally covered 2,000 ft northwest and southeast of the structure and was extended to 4,200 ft northwest and 4,000 ft southeast of the breakwater after the second survey as shown in Figure 6. Each survey consisted of 37 profile lines extending from the existing seawall seaward approximately $750 \mathrm{ft}$. Profile line spacing 


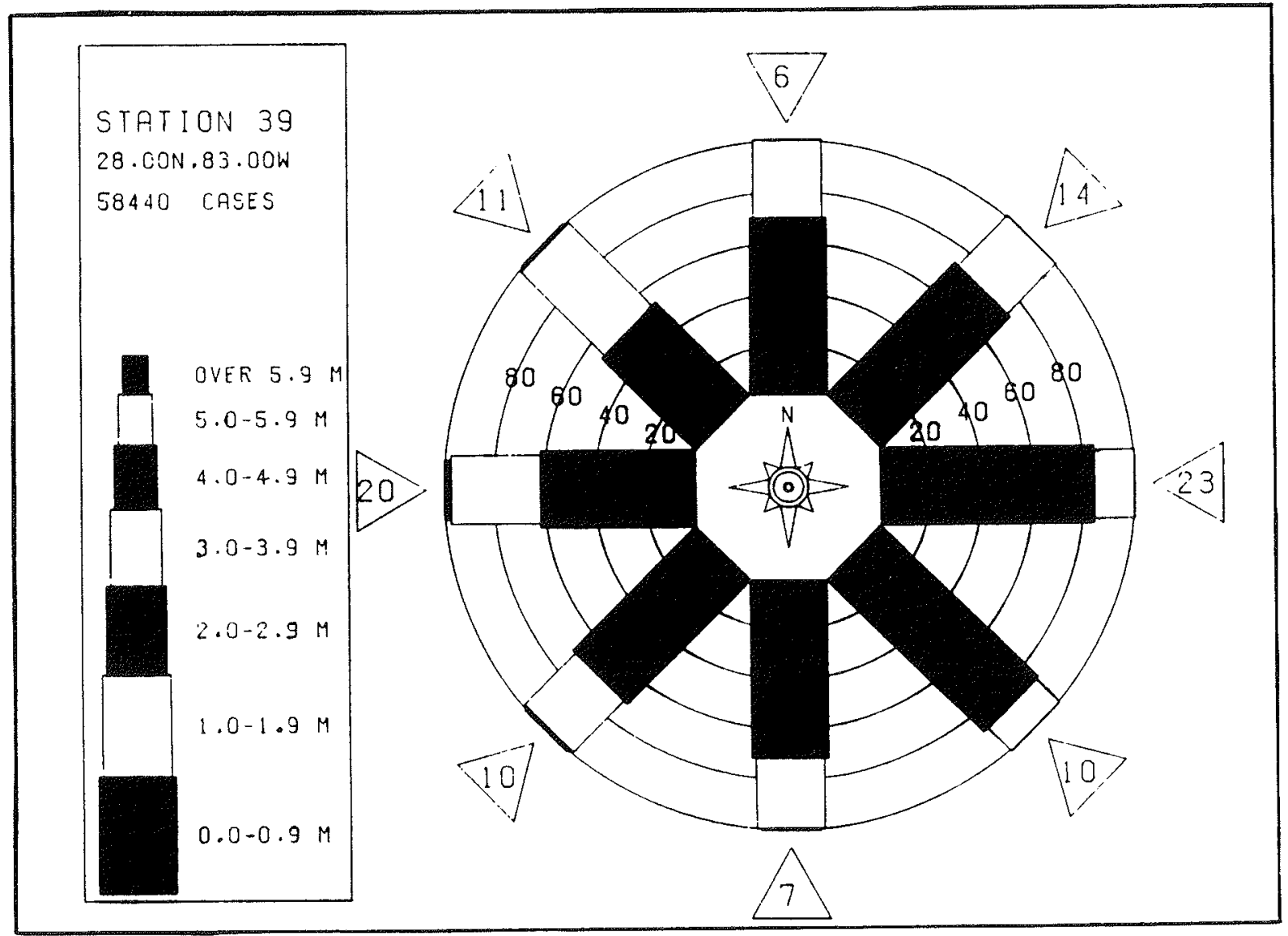

Figure 3. WIS hindcast wave rose for the Redington Shores vicinity (after Hubertz and Brooks 1989) 


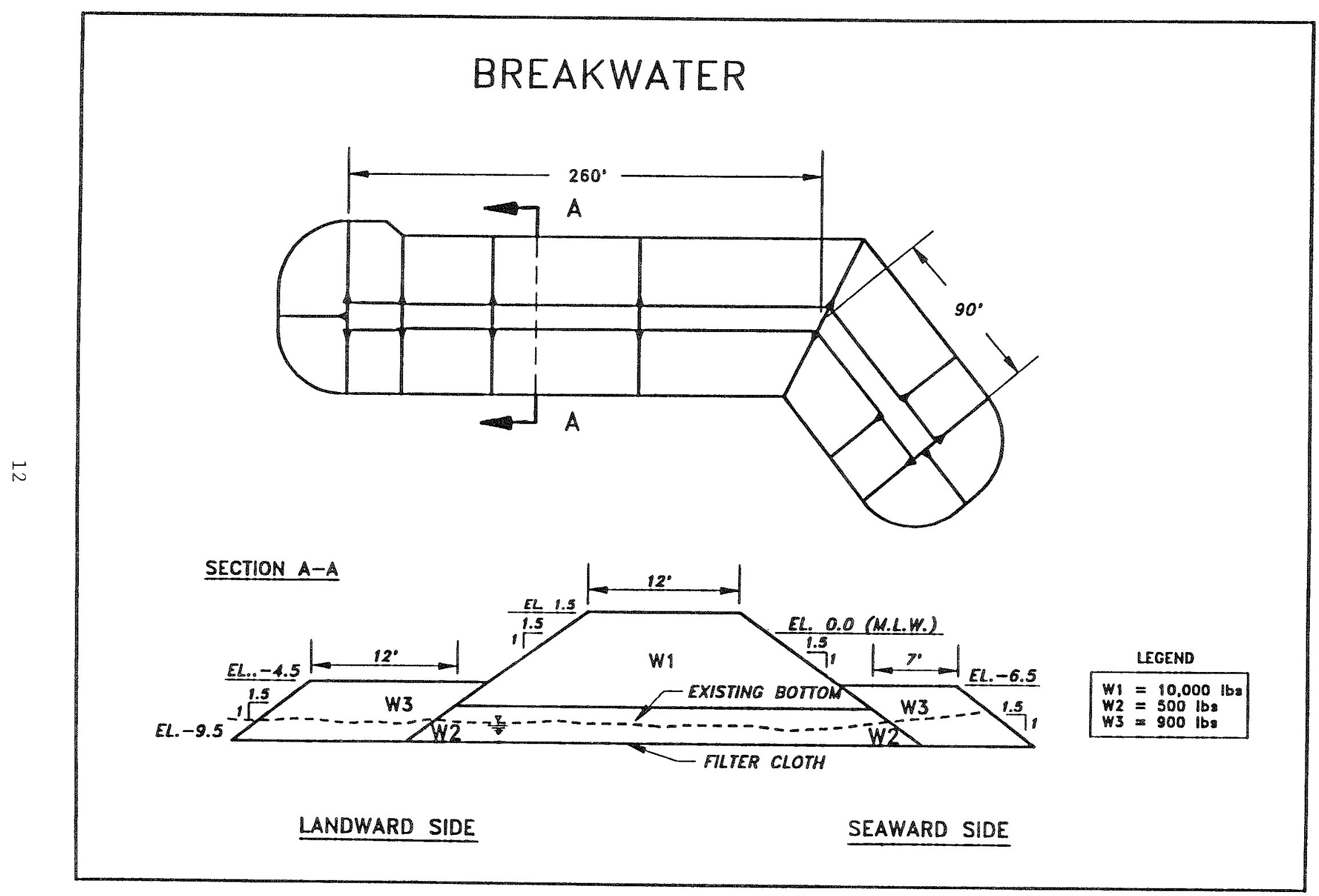

Figure 4. Plan view and cross section of Redington Shores breakwater (after U.S. Army Corps of Engineers 1989) 


\begin{tabular}{|c|c|c|c|c|c|c|c|}
\hline & 1984 & 1985 & 1986 & 1987 & 1988 & 1989 & 1990 \\
\hline CONSTRUCTION & & $\begin{array}{c}\text { DEC } \\
\text { Construction } \\
\text { Began }\end{array}$ & $\begin{array}{c}\text { JAN } \\
\text { Construction } \\
\text { Complete }\end{array}$ & & $\begin{array}{c}\text { AUG } \\
\text { Lower Crest } \\
\text { Renourish } \\
\end{array}$ & & \\
\hline $\begin{array}{l}\text { BATHYMETRIC } \\
\text { AND BEACH } \\
\text { PROFILE } \\
\text { SURVEYS }\end{array}$ & $\begin{array}{c}\text { SEPT } \\
\text { Dean } \\
\& \\
\text { Pope }\end{array}$ & & $\begin{array}{c}\text { APR } \\
\text { Jacksonville } \\
\text { Nov } \\
\text { Jacksonville } \\
\end{array}$ & $\begin{array}{c}\text { AUG } \\
\text { (Mo } \\
\text { Jack }\end{array}$ & $\begin{array}{l}\quad \quad \text { SEPT } \\
\text { Jacksonville } \\
\text { THRU FEB } \\
\text { nthly) } \\
\text { sonville } \\
\end{array}$ & $\begin{array}{c}\text { JULY } \\
\text { Jacksonville }\end{array}$ & \\
\hline $\begin{array}{l}\text { AERIAL } \\
\text { SURVEYS }\end{array}$ & & $\begin{array}{c}\text { MAY } \\
\text { Dean \& Pope }\end{array}$ & $\begin{array}{c}\text { JAN } \\
\text { APR } \\
\text { OCT } \\
\text { Dean \& Pope }\end{array}$ & $\begin{array}{c}\text { AUG THRU } \\
\text { DEC } \\
\text { (Monthly) } \\
\text { Jacksonville }\end{array}$ & & & \\
\hline HURR I CANES & & $\begin{array}{c}\text { ELENA } \\
8 / 30 \cdot 9 / 02 \\
\text { JUAN } \\
10 / 29 \cdot 11 / 01 \\
\text { KATE } \\
11 / 17 \cdot 11 / 21\end{array}$ & & & & & \\
\hline
\end{tabular}

Figure 5. Activities associated with Redington Breakwater (1984-1989)

varied from $50 \mathrm{ft}$ in the vicinity of the breakwater to $500 \mathrm{ft}$ on the northwesternmost and southeasternmost ends of the study area.

11. The first two post-construction beach and nearshore bathymetric surveys were conducted in April and November of 1986. Following these two surveys, the survey limits were extended to broaden the evaluation of the effects of the structure on adjacent beaches. An extensive monthly monitoring program was also begun in August 1987 to assess the seasonal performance of the breakwater. Surveys were performed every month from August 1987 to February 1988. Beach profile surveys were also performed after the completion of the August 1988 renourishment program. The Jacksonville District conducted surveys in September 1988 and July 1989. From the post-construction survey in April 1986 to the post-renourishment survey in July 1989, a total of 12 surveys were performed by the Jacksonville District.

12. The pre-construction survey as well as the first two postconstruction surveys, performed in April and November 1986, were analyzed by 


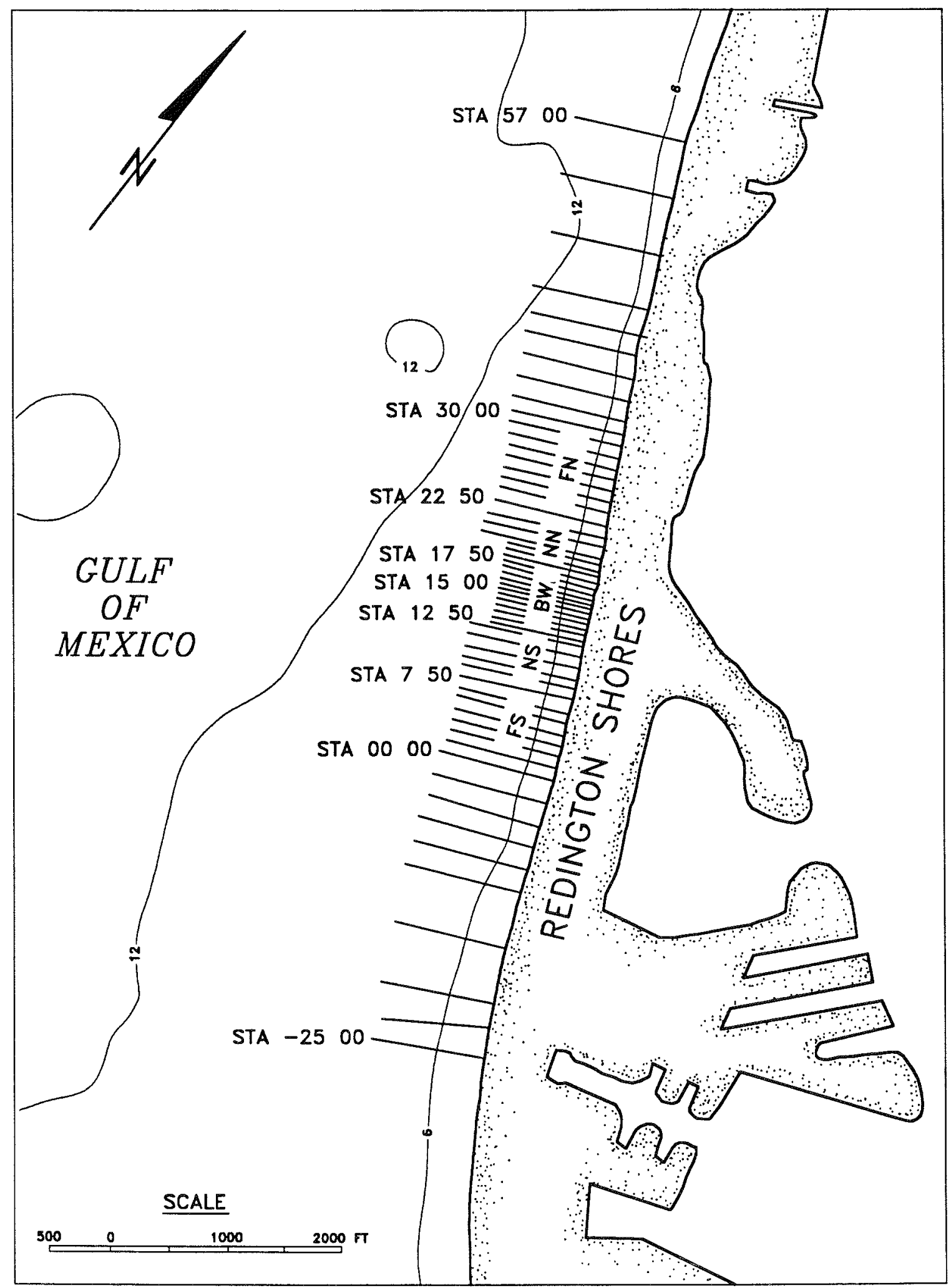

Figure 6. Profile line locations at Redington Shores (after U.S. Army Corps of Engineers 1989) 
Dean and Pope and discussed in their 1987 report. All of the other surveys were analyzed by the Jacksonville District in their 1989 report.

13. The Jacksonville District also performed aerial surveys during May 1985, January 1986, April 1986, and October 1986. After that, they performed monthly aerial surveys between August 1987 and December 1987 as well as another single survey in September 1988. Dean and Pope (1987) discussed the first four surveys and the Jacksonville District (U.S. Army Corps of Engineers 1989) discussed all subsequent surveys. No volumetric change analyses were performed on the aerial photographs. Appendix A presents a compilation of aerial photographs collected by the Jacksonville District from August 1987 to December 1987 and September 1988.

14. Contour plots for many of the bathymetric surveys performed by the Jacksonville district are presented in this report. The plots, which were generated using the Contour Plotting System software (CPS-3) developed by Radian Corporation, are used as a qualitative assessment of the areas of erosion and accretion. 


\section{PART II: SURVEY RESULTS AND DISCUSSIONS}

\section{Initial Shoreline Response}

15. Figure 7 shows the shoreline positions derived from aerial photographs and presented in Dean and Pope (1987). The aerial surveys were performed May 1985, January 1986, April 1986, and October 1986. Since no record of the tide level was available for the periods of the aerial surveys, no correction for tidal effects was made. Therefore, the shoreline positions shown in the figure may only be compared qualitatively. The average tide range in the study area is only $1.2 \mathrm{ft}$ and the spring tide range is $2.3 \mathrm{ft}$.

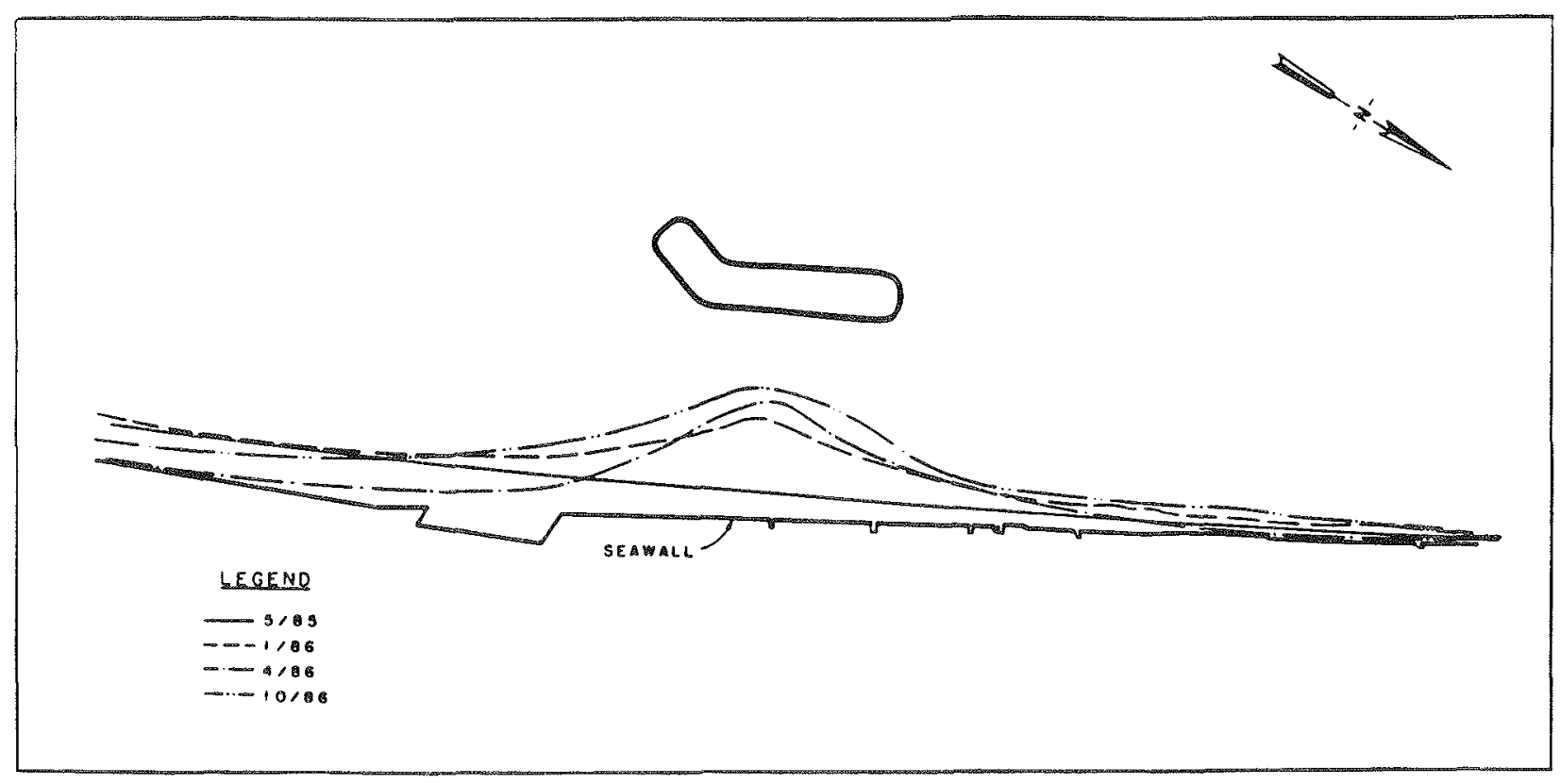

Figure 7. Compilation of shorelines digitized from aerial photographs (after Dean and Pope 1987)

16. The May 1985 shoreline shown in Figure 7 represents the preconstruction shoreline condition and the other three shorelines represent post-construction conditions. Dean and Pope (1987) suggest that the subaerial area in the lee of the breakwater has increased between the completion of construction and October 1986, even though the areas northwest and southeast of the project may have eroded. 
17. Between May 1985 and January 1986, three hurricanes, Elena, Juan, and Kate occurred in the region. Elena became a hurricane on August 301985. Although Hurricane Elena did not make landfall in Florida, it stalled off Cedar Key, FL for about 24 hours. The generally south-southwest winds caused an increase in wave energy and a storm surge along the west coast of Florida in the vicinity of Redington Beach. The hurricane caused extensive damage to the barrier islands and Pinellas County was declared a Federal Disaster area. Both Hurricanes Juan (October 29 - November 1) and Kate (November 17-21) had minimal impacts on the west coast of Florida during their passage through the Gulf of Mexico (Davis and Andronaco 1987).

18. Dean and Pope (1987) analyzed the September 1984 pre-construction bathymetric survey as well as the post-construction April and November 1986 surveys. Subsequent to the pre-construction survey the three hurricanes struck the area. These hurricanes make the representativeness of the September 1984 survey, conducted a full 15 months prior to construction, to the preproject shoreline condition questionable. According to Davis and Andronaco (1987), following Hurricane Elena the beach profile was "low, narrow and had a pronounced ridge about $0.3 \mathrm{~m}$ ( $1 \mathrm{ft}$ ) high." They also describe a subtidal. ephemeral bar offshore of the ridge. Following the passage of Hurricane Juan, they describe the beach as "changed remarkably." The ridge and ephemeral bar had moved landward and the beach had built up in front of the seawall. Hurricane Kate subsequently removed a low relief ridge that was present after Juan (Davis and Andronaco 1987). Dean and Pope (1987) also observed that Hurricane Elena moved the contours landward. This observation suggests that the beaches were steepened by the hurricane but that there were no dramatic bathymetric modifications. The post-storm beach recovery processes probably allowed the beach to return to somewhat normal conditions. Lack of other data forced the use of the September 1984 survey to approximate the pre-project beach condition.

19. Dean and Pope (1987) computed the volumetric changes between the September 1984 and November 1986 bathymetric surveys. They presented these findings in a table which is reproduced here as Table 2. The different areas evaluated for volumetric changes may be seen in Figure 6 . The area labeled "BW" includes the $500 \mathrm{ft}$ of the shoreline directly across from the breakwater (between STA $12+50$ and STA 17+50) and offshore to the $-10 \mathrm{ft} \mathrm{MLW} \mathrm{contour.} \mathrm{The}$ areas "NS" (Near South) and "NN" (Near North) include the areas between STA 
Table 2

Volume Changes from Bathymetric Surveys (Dean and Pope 1987)

\begin{tabular}{|c|c|c|c|c|c|}
\hline \multirow[b]{2}{*}{$\begin{array}{l}\text { Area De- } \\
\text { scription }\end{array}$} & \multirow[b]{2}{*}{$\begin{array}{l}\text { Length of } \\
\text { Shoreline } \\
\mathrm{ft}\end{array}$} & \multicolumn{2}{|c|}{$9 / 84-4 / 86$} & \multicolumn{2}{|c|}{$4 / 86-11 / 86$} \\
\hline & & $\begin{array}{c}\text { Volume } \\
\text { Change } \\
\mathrm{yd}^{3}\end{array}$ & $\begin{array}{l}\text { Per Shore- } \\
\text { line Width } \\
\mathrm{yd}^{3} / \mathrm{ft} \\
\end{array}$ & $\begin{array}{l}\text { Volume } \\
\text { Change } \\
\mathrm{yd}^{3} \\
\end{array}$ & $\begin{array}{l}\text { Per Shore- } \\
\text { line Width } \\
\mathrm{yd}^{3} / \mathrm{ft} \\
\end{array}$ \\
\hline FS & 750 & $-15,820$ & -21.1 & $-3,233$ & -4.3 \\
\hline NS & 500 & 1,596 & 3.2 & 2,215 & 4.4 \\
\hline $\mathrm{BW}$ & 500 & 28,176 & 56.4 & -220 & -0.4 \\
\hline NN & 500 & 799 & 1.6 & 1,786 & 3.6 \\
\hline FN & 750 & $-4,790$ & -6.4 & 782 & 1.0 \\
\hline
\end{tabular}

$7+50$ and STA $12+50$, and between STA $17+50$ and STA $22+50$, respectively. The areas "FS" (Far South) and "FN" (Far North) are the furthest southeastern and northwestern limits of the data sets, beginning approximately $750 \mathrm{ft}$ southeast (between STA $00+00$ and STA 7+50) and northwest (between STA 22+50 and STA $30+00)$ of the breakwater's centerline, respectively.

20. The April 1986 survey was conducted approximately 3 months after the completion of construction. The survey data includes the 30,000 cu yd of material placed onshore of the breakwater. It may appear that the sediment in the tombolo simply represents the placed initial fill. But, without this fill material, the tombolo probably would have been built up to some extent from littoral processes anyway, due to the presence of the breakwater.

21. As may be seen in Figure 7, the April 1986 shoreline shows a loss in planform areas both northwest and southeast of the project relative to the two previous shorelines. Compared to the April 1986 shoreline position, the October 1986 shoreline shows beach accretion both northwest and southeast, with more accretion south than north. This result is not surprising because the local wind (and presumably wave) directions during the spring and summer are mild and mostly southerly; during the fall and winter the winds are strong and mostly northerly. The stronger north winds during January through April caused the sediment to erode southeast of the breakwater but was gradually recovered during the summer.

22. The annual natural beach erosion rate estimated for the Redington Shores area is approximately 1 cubic yard per foot of shoreline (U.S. Army 
Corps of Engineers 1984). The rate of accretion in the areas close to the breakwater exceed the natural value substantially. Figure 8 a generated by CPS, shows the patterns of erosion and deposition in the nearshore area being studied for the September 1984 to April 1986 time period. It is evident that accretion occurred around the breakwater in all directions. It is also evident that erosion did occur at areas further southeast and further northwest of the structure.

23. It is likely that the nearshore bathymetric changes illustrated by Figure $8 \mathrm{a}$ and Table 2 are caused by the Redington shores breakwater. The long time span between the two surveys, September 1984 and April 1986 respectively, and the occurrence of Hurricane Elenas, Juan, and Kate in 1985 make the interpretation of the computed changes more or less qualitative in nature. In both the September 1984 - April 1986 and April 1986 - November 1986

comparisons, the "Far South" area has a higher erosion rate than the "Far North" area. Apparently, the updrift trapping of the breakwater-tombolo "groin," combined with the strong northern winds eroding the southeastern area at a faster rate than the northwestern, caused these unbalanced impacts on the shorelines.

\section{$\underline{\text { Post-Construction Shoreline Response }}$}

24. From the first post-construction survey, conducted in April 1986 , to the last survey performed in February 1988, prior to the Redington Shores beach Phase 1 renourishment (August 1988), the shoreline response to the breakwater was detailed by the Jacksonville District (U.S. Army Corps of Engineers 1989). The Jacksonville District summarized the volume changes in a table which is reproduced here as Table 3 . This table summarizes the changes in sediment volume computed for each area between every two adjacent profile lines for the post-construction period. Since all of the profile line spacings are not the same, the Jacksonville District computed the unit rates of change of sediment volume (cubic yards) per linear distance of the shoreline (feet). These values were then used to compare erosion (negative values) or accretion (positive values) in the Redington Shores area.

25. From April to November 1986, a net accretion of 7,254 cubic yards occurred over the entire length of monitored beach even though a late April storm that year caused some erosion in the area immediately behind the 


\section{CONTOUR CHANGES}

\section{SEPT' 84 - APRIL' 86}

(a)

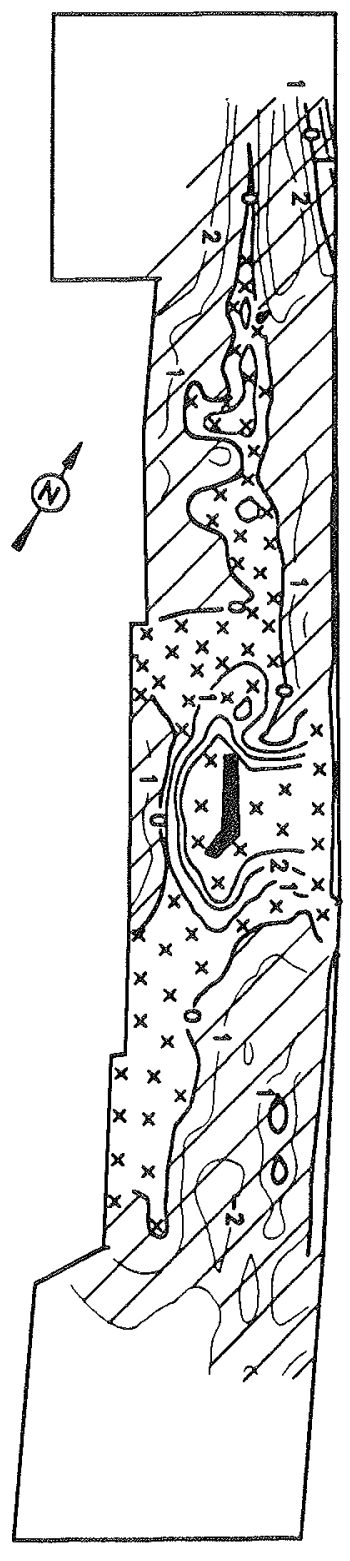

APRIL'86 - NOV' 86

(b)

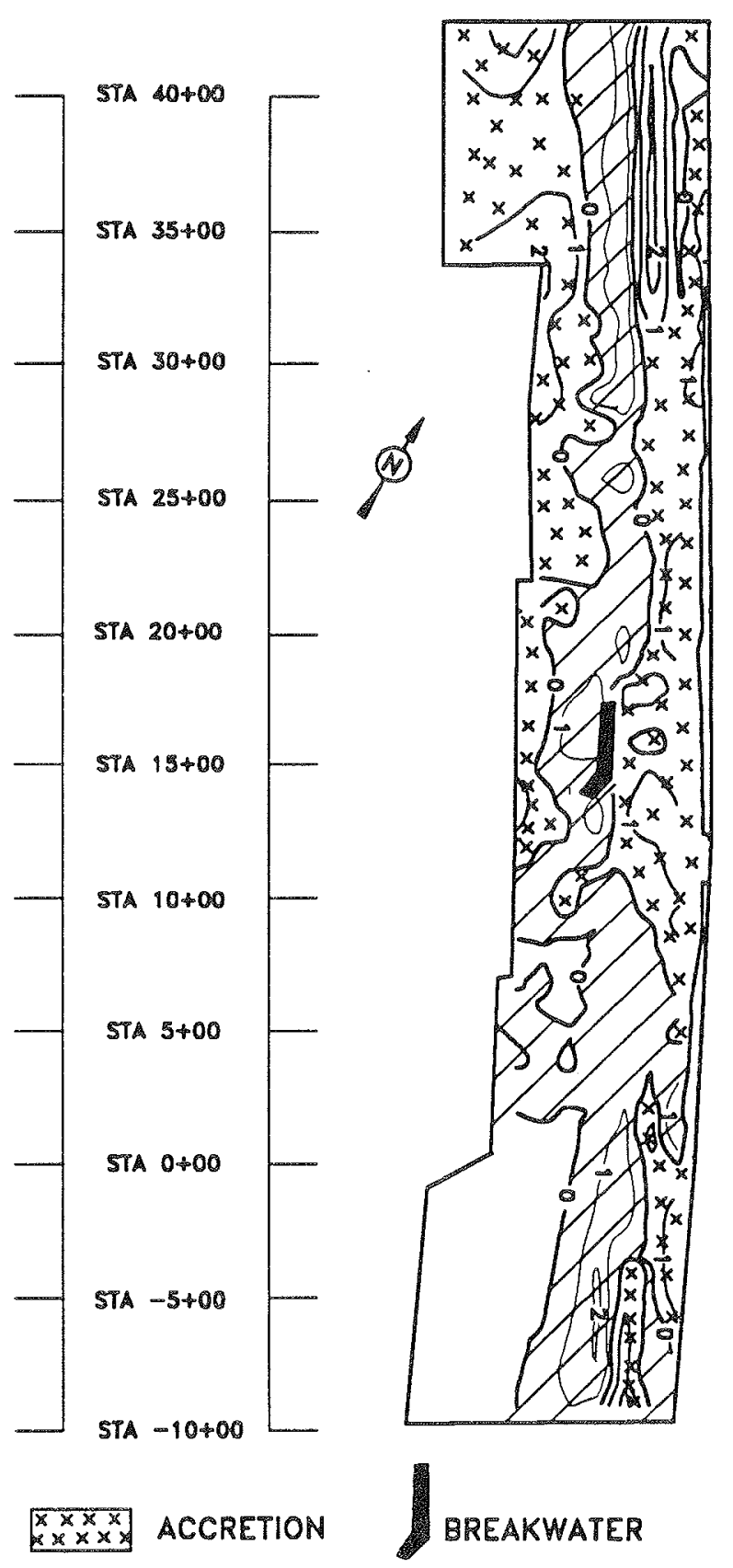

Figure 8 . Contour changes 
Table 3

Redington Shores Breakwater Volumetric Changes

(After U.S. Army Corps of Engineers 1989)

Changes in Volume (Cubic Yards) Over Time Period Indicated

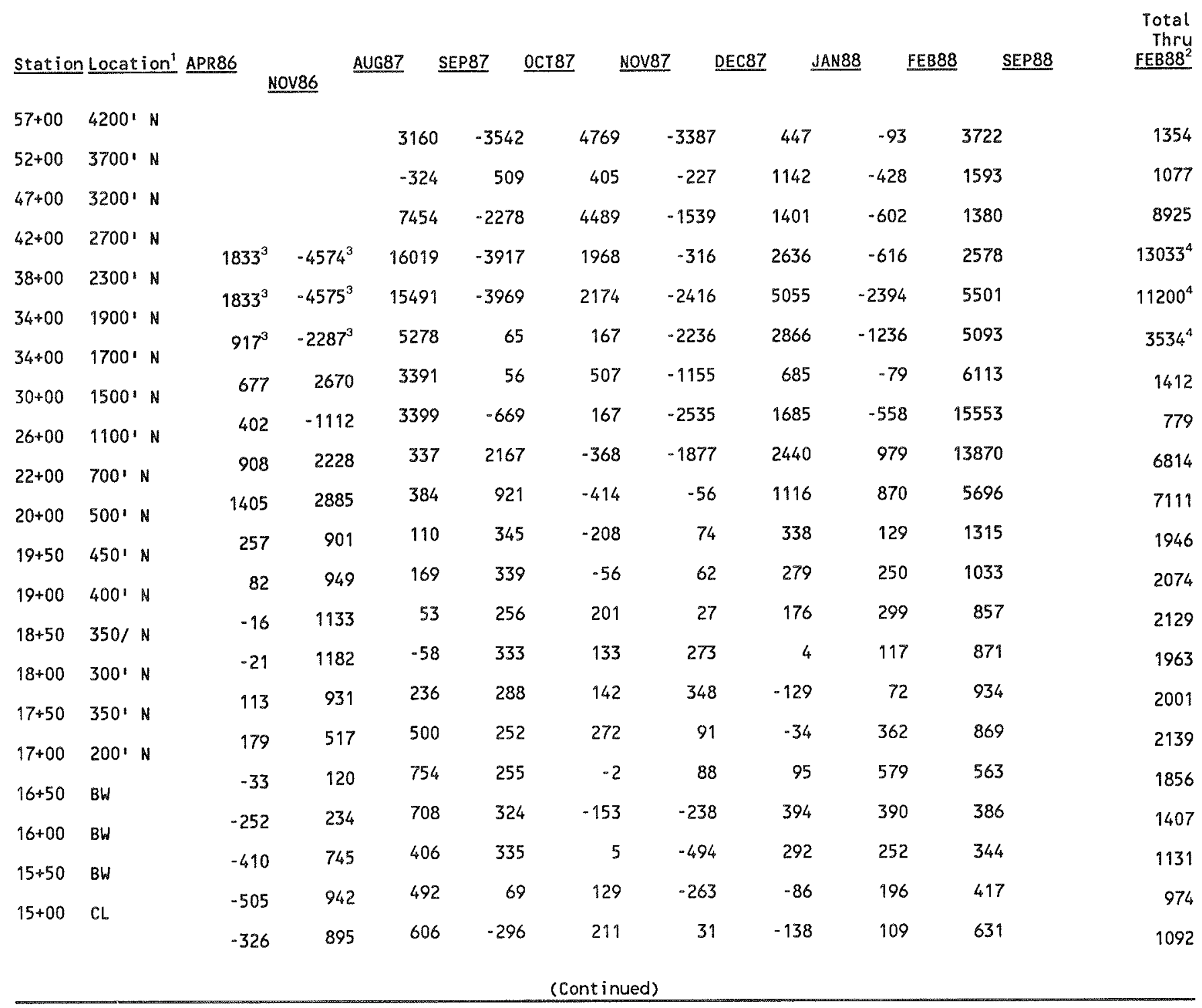

${ }^{1} \mathrm{~N}=$ north of breakwater; $\mathrm{S}=$ south of Breakwater; $\mathrm{BW}=$ behind breakwater; $\mathrm{CL}=$ centerline of breakwater.

${ }^{2}$ Represents volume changes during monitoring period April 1986 - February 1988. Volume changes from February 1988 through september 1988 include effects of beach renourishment and are not reflected in this total.

${ }^{3}$ Actual volume measured during April 1986 and November 1986 surveys extends from stations $32+00$ to $42+00$ (north side, and from stations $-10+00$ to $00+00$ (south side). Values indicated in Table 1 have been interpolated by distance between the intermediate stations in order to allow volume changes to be more easily compared to the more recent surveys, which incorporate these intermediate stations.

"Total includes interpolated value described in 3 above. 
Table 3 (Concluded)

Changes in Volume (Cubic Yards) Over Time Period Indicated

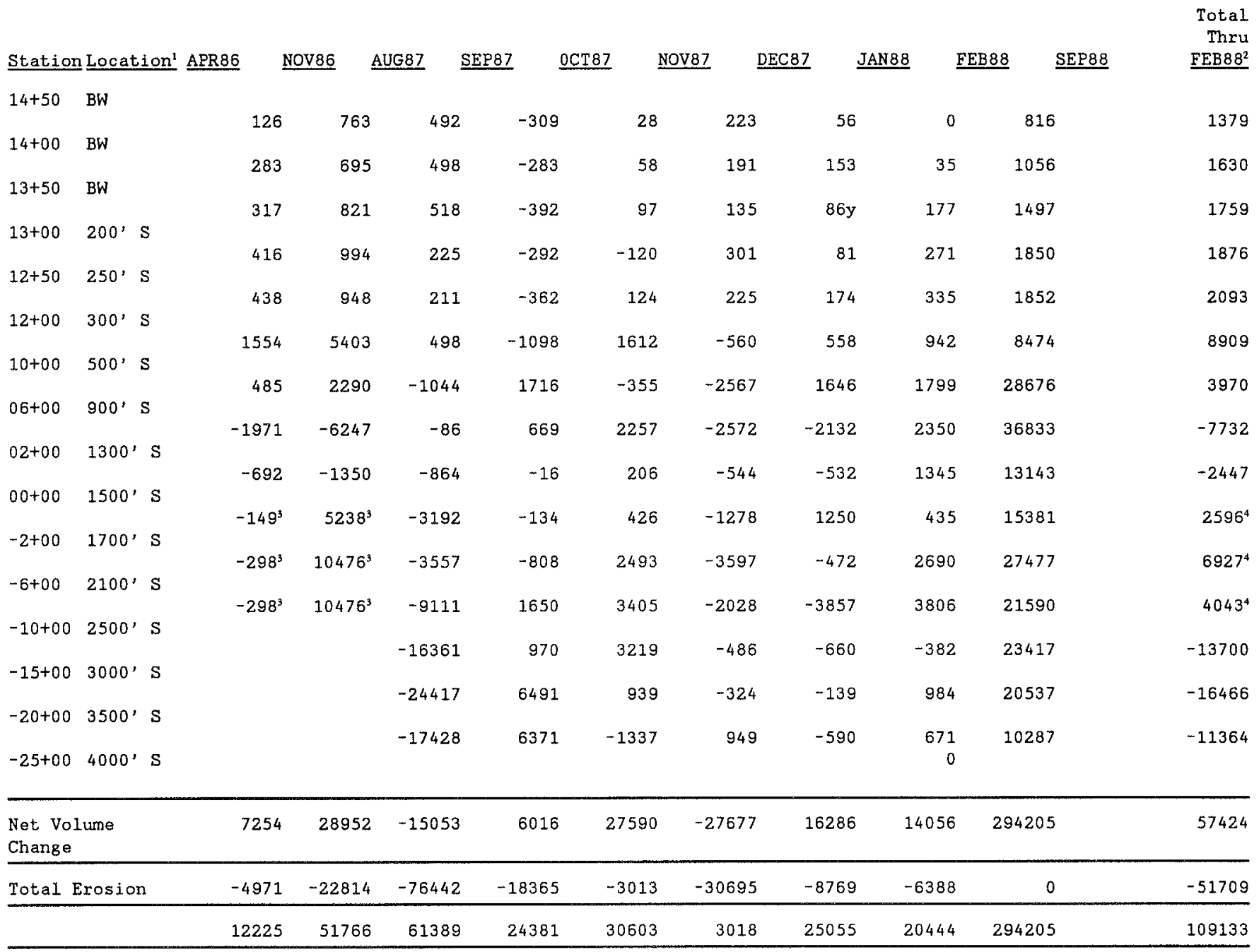


breakwater. Some minor erosion occurred in the "Far South" area while accretion occurred in the "Far North" area as may be seen in Figures $8 \mathrm{~b}$ and 9a. This accretion/erosion at the far fields completely reversed in the following period between November 1986 and August 1987 as shown in Figures 9b and 10a. Except for the minor erosion in the reach between STA $00+00$ and STA 06+00 (Table 3 and Figure 9b), the southern shoreline exhibited significant beach recovery processes. The reversal in the erosion-accretion trend between the two time periods, April 1986 - November 1986 and November 1986 - August 1987, may be due to seasonal events. Figures $10 \mathrm{~b}$ and $11 \mathrm{a}$ show the erosiondeposition pattern for the period between August 1987 and February 1988. In this time period, the far field locations of erosion-accretion again reversed from the previous November 1986 - August 1987 period.

26. Although both erosion and accretion occurred along different reaches of the study area within the same time period, the net sediment volume changes of the entire study areas for both the November 1986 - August 1987 and August 1987 - February 1988 periods are positive (accretion) $(28,952 \mathrm{cu} y d$ and $21,218 \mathrm{cu}$ yd, respectively). For the total 22 -month period from April 1986 to February 1988, the net increase in sediment volume within the study area is $57,424 \mathrm{cu} y d$. Since the Redington Shores beach is a naturally eroding coastline, this increase in sediment volume during the post-construction period is most likely attributed to the presence of the offshore breakwater and the placement of 30,000 c.y. of beach sand.

27. A monthly monitoring plan was initiated in August 1987 and terminated in February 1988. The calculated volumetric changes during the monthly monitoring period are also listed in Table 3. The month-to-month changes in the erosion/accretion processes are very scattered, apparently reflecting the weather and littoral conditions of those relatively short durations.

28. The rates of volume change per foot of shoreline between April 1986 - January 1988 are shown in Figure $11 \mathrm{~b}$ and Table 3. The results reveal the impact of the structure on the adjacent shoreline. During the postconstruction period, April 1986 to February 1988, the shoreline and the nearshore region northwest of STA $06+00$ accreted at an annual average rate of $14.4 \mathrm{cu} \mathrm{yd/ft}$. However, the area southeast of STA 6+00, in general, was experiencing erosion at a rate of $26.6 \mathrm{cu} y d / \mathrm{ft}$. The interruption of littoral 


\section{VOLUME CHANGES \\ APRIL'86 - NOVEMBER' 86}
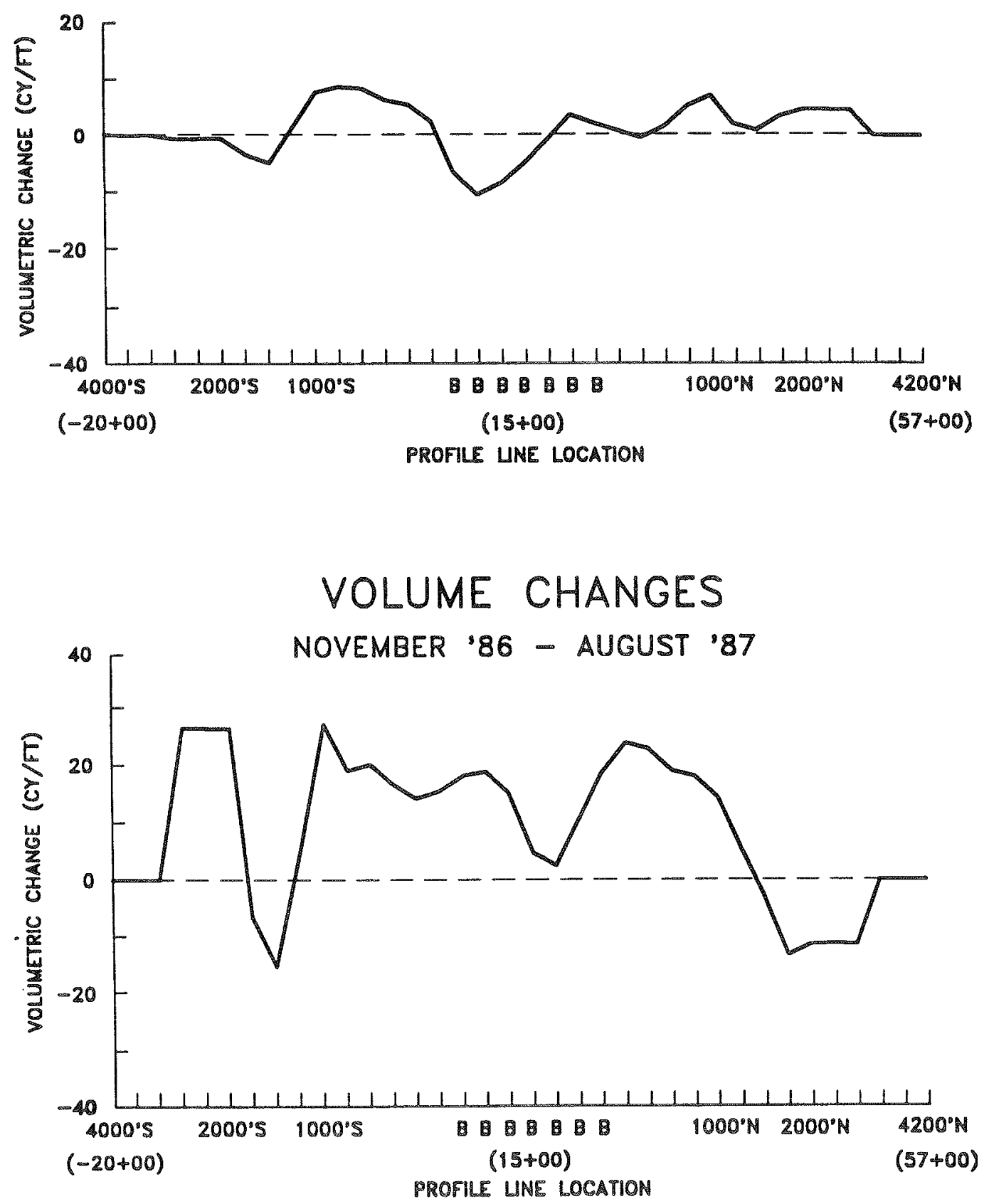

Figure 9. Redington Shores breakwater volume changes (after U.S. Army Corps of Engineers 1989) 


\section{CONTOUR CHANGES}

DEC '86 - AUG' 87

AUG '87 - FEB' 88
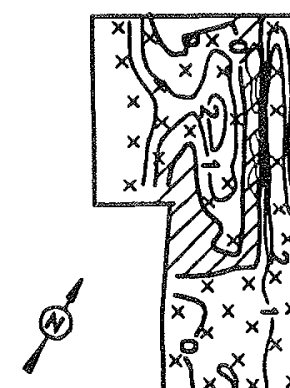

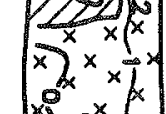

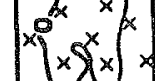

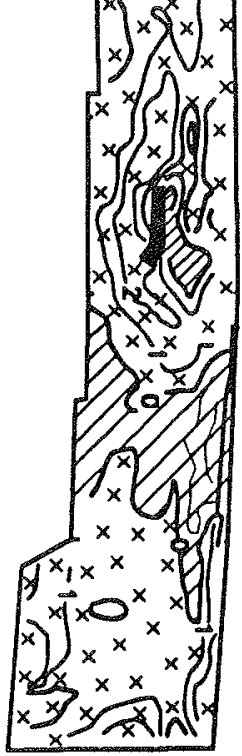

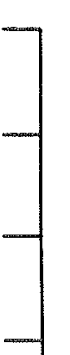

STA $55+00$

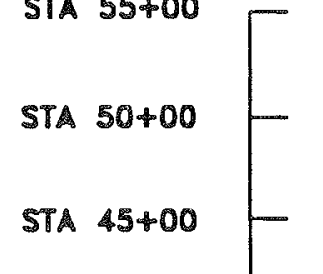

STA $40+00$

STA $35+00$ STA

STA $30+00$

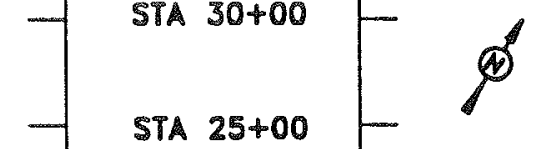

$-1$

$-$

STA $20+0$

STA $15+00$

STA $10+00$

$-1$

$-1$

$-1$

$-$

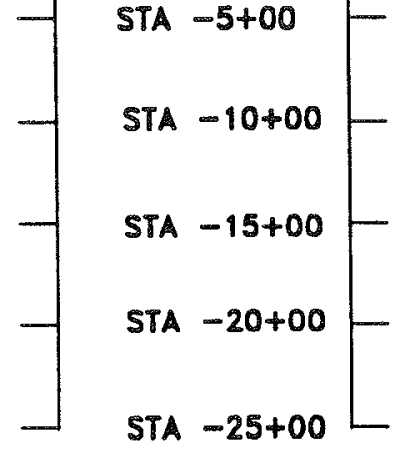

STA $5+00$

STA $0+00$

STA $-5+00$

QZZZ EROSION
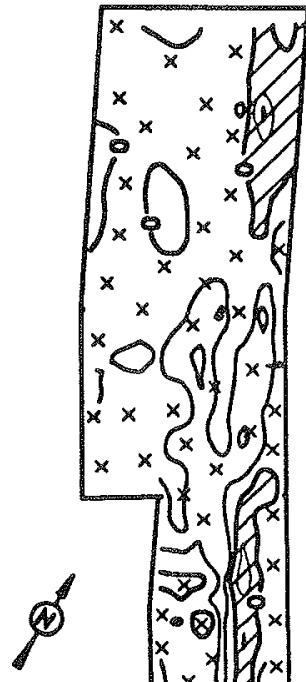

$0 \times 6$

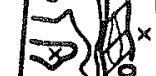

$\left(\begin{array}{ll}\infty \\ x_{\infty} & 0 \\ x & 0\end{array}\right]$

$\int^{x} \times y(x$

$\int_{x}^{x} x, y \mid x$

$\left[\begin{array}{cc}x & x \\ x & x \\ x & x\end{array}\right] x$

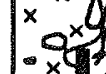

$\times x \times x$ $x 10 \times$
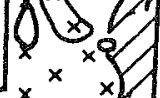

$x=x^{x}$
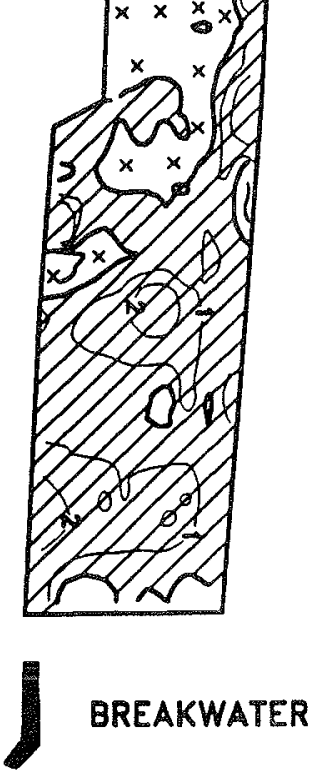

Figure 10. Contour changes 


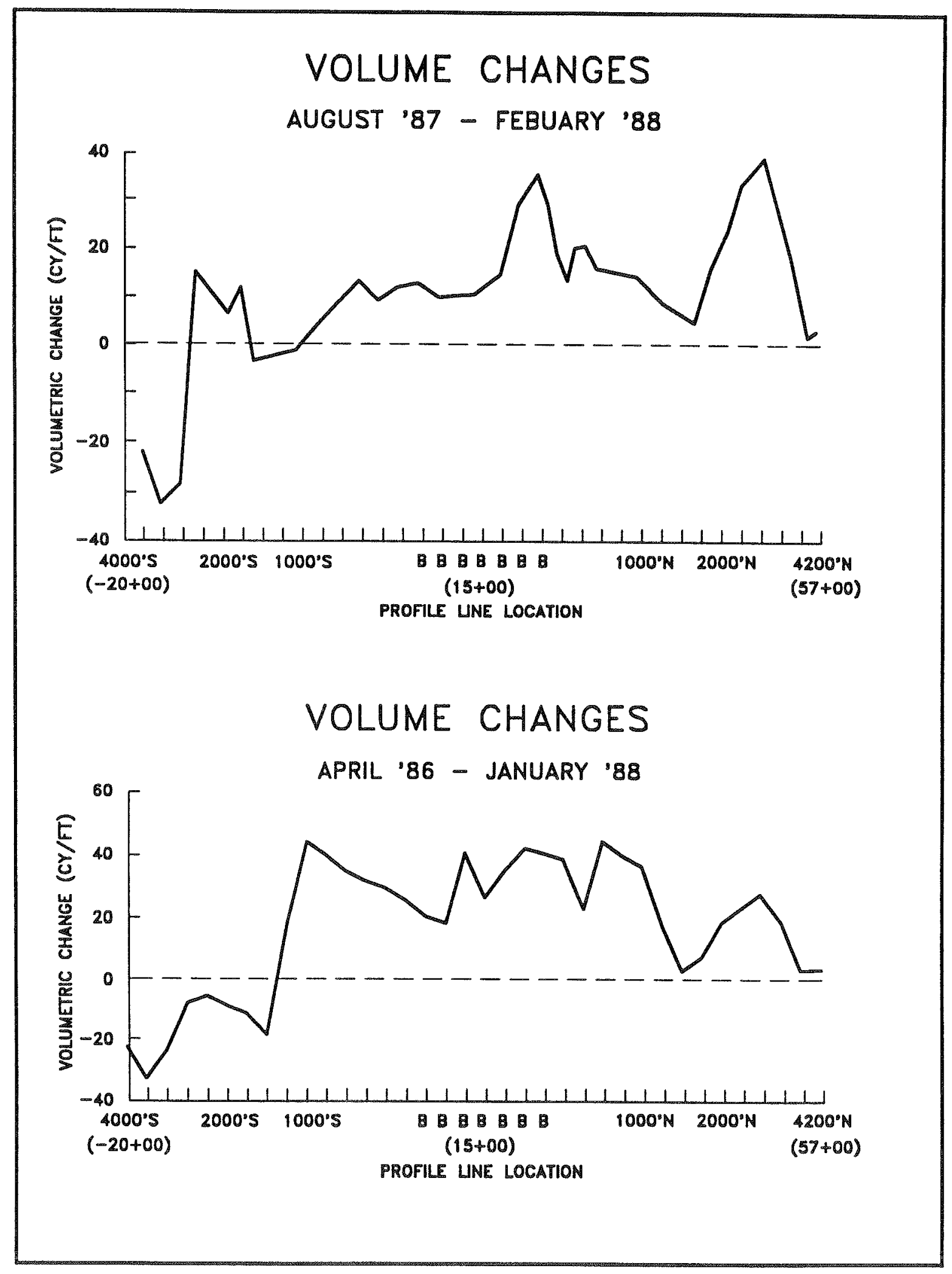

Figure 11. Redington Shores breakwater volume changes (after U.S. Army Corps of Engineers 1989) 
transport by the tombolo may be responsible, in part, for the erosion that occurred at the downdrift side of the breakwater.

\section{Post-Renourishment Shoreline Response}

29. During August 1988 the Redington Shores beach was re-nourished with approximately $380,000 \mathrm{cu}$ yd of sand. At the same time, the crest height of the breakwater was lowered to increase the transmissibility of wave energy. The increase in sand volume calculated from February 1988 to September 1988 and presented in Table 3 is $294,205 \mathrm{cu}$ yd. The difference between the calculated volume and the estimated placement volume may be attributed to the possible winnowing loss during placement or erosion loss from wave action during the February to September period. Figure 12a shows that accretion occurred over most of the study area, except for one small area offshore of the breakwater and two small areas near the northwestern study limit.

30. Figure $12 \mathrm{~b}$ shows the bathymetry changes between September 1988 and July 1989. During this period, accretion occurred in a small area seaward of and immediately north of the breakwater and in the extreme northwestern reach of the study area. Significant areas of erosion southeast and northwest of the breakwater are apparent. These patterns are expected because of the strong northern winds experienced during this time period. 


\section{CONTOUR CHANGES}

FEB ' 88 - SEPT ' 88

SEPT '88 - JULY'89
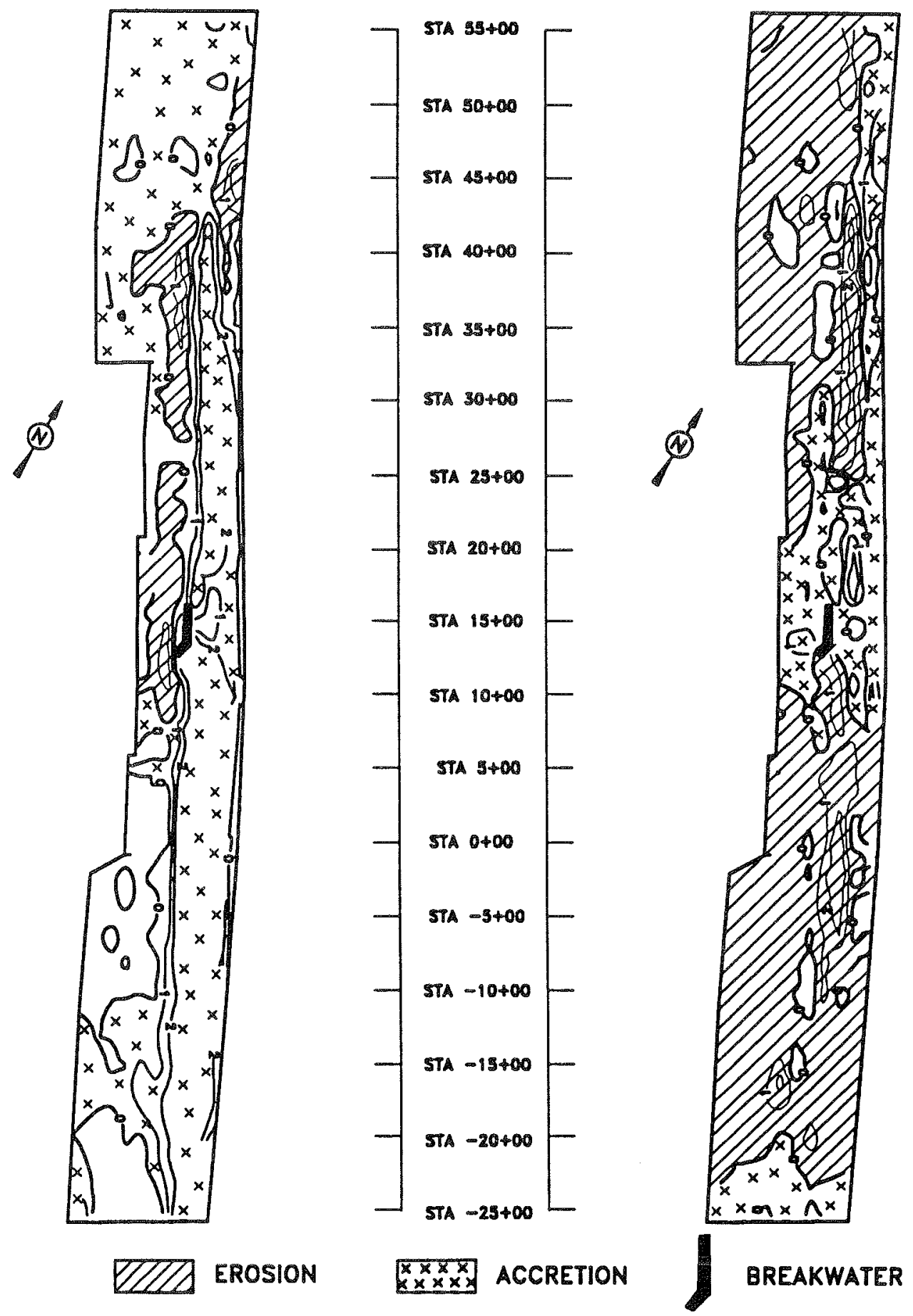

Figure 12. Contour changes 
PART III: SUMMARY AND CONCLUSIONS

31. The success of the Redington Shores breakwater has been mixed. It has accomplished its design function of stabilizing the eroding beach immediately behind the structure. However, the breakwater has not accomplished its function of bypassing the majority of longshore sediment transport. The total amount of accreted sediment volume within the study area is uncertain due to Hurricanes Elena, Juan, and Kate, which distorted the baseline condition of the study area prior to the project construction. The initial shoreline response to the presence of the breakwater was relatively rapid and resulted in substantial growth of a tombolo in the three months after the completion of breakwater construction. From April 1986 to February 1988, the postconstruction period, a total of $57,000 \mathrm{cu}$ yd of sand accumulated in the study area. However, the distribution of the accumulated sand is not uniform over the 8,000-ft shoreline. The majority of the sediment was deposited in the immediate vicinity and northwest of the structure. Erosion continued about $600 \mathrm{ft}$ southeast of the breakwater.

32. Variations in the erosion/accretion pattern are apparent in the study area during different survey periods. It is possible that the periodic shifts were due to seasonal events. However, the periods of data available were non-uniform, so no seasonal comparison may be made.

33. The magnitude of erosion southeast of the breakwater was generally larger than that northwest of the breakwater. This observation is consistent with the seasonal variation in wind direction and the inferred littoral transport processes of the region. The interruption in the net southerly longshore transport by the low-water tombolo is apparently responsible for the erosion southeast of the structure.

34. The beach area immediately onshore of the breakwater was fairly stable during the monitoring period. The tombolo accreted continuously after the April 1986 storm. Minor erosion in the lee of structure occurred between the April 1986 and November 1986 surveys. Perhaps, the wave energy attenuation by the Redington Shores breakwater is too effective. A slightly less effective structure may be able to bypass the littoral sand to either direction and alleviate the erosion problem south of the structure. This may be accomplished by 1) locating the structure further offshore, 2) constructing segmented breakwaters of shorter structure length with a relatively large gap 
spacing, or 3) increasing the transmissibility of the structure by lowering the crest height (U.S. Army Corps of Engineers 1989). 


\section{REFERENCES}

Davis, R. A., Jr., Hine, A. C., and Belknap, D. F. (eds.). 1985. "Geology of the Barrier Island and Marsh-Dominated Coast, West-Central Florida," 1985 Annual Meeting and Exposition, Geological Society of America.

Davis, R.A., Jr., and Andronaco, M. 1987. "Impact of Hurricanes on Pinellas County, Florida 1985," Florida Sea Grant Publication. Technical Paper No. 51.

Dean, J. L., and Pope, J. 1987. "The Redington Shores Breakwater: Initial Response," Proceedings of Coastal Sediments '87, American Society of Civil Engineers, New Orleans, LA.

Hubertz, J. M., and Brooks, R. M. 1989. "Gulf of Mexico Hindcast Wave Information," WIS Report 18, US Army Engineer Waterways Experiment Station, Vicksburg, MS .

Rosen, D. S. 1976. "Beach and Nearshore Sedimentation of Caladesi Island State Park, Pinellas County, Florida," unpublished M.S. thesis, University of South Florida.

Terry, J. B., and Howard, E. 1986. "Redington Shores Beach Access Breakwater," Shore and Beach, Volume 54, No. 4, pp 7-9.

U.S. Army Corps of Engineers, Jacksonville District. 1984. "Pinellas County, Florida Beach Erosion Control Project, Sand Key Segment," US Army Corps of Engineers.

- 1989. "Pinellas County, Florida, Beach Erosion Control Project, Monitoring Report, Redington Shores Breakwater," US Army Corps of Engineers. 
APPENDIX A: AERIAL PHOTOGRAPHS OF REDINGTON SHORES BREAKWATER

Monthly aerial photographs of Redington Shores breakwater are presented for the periods July 1987 to December 1987 and September 1988. 


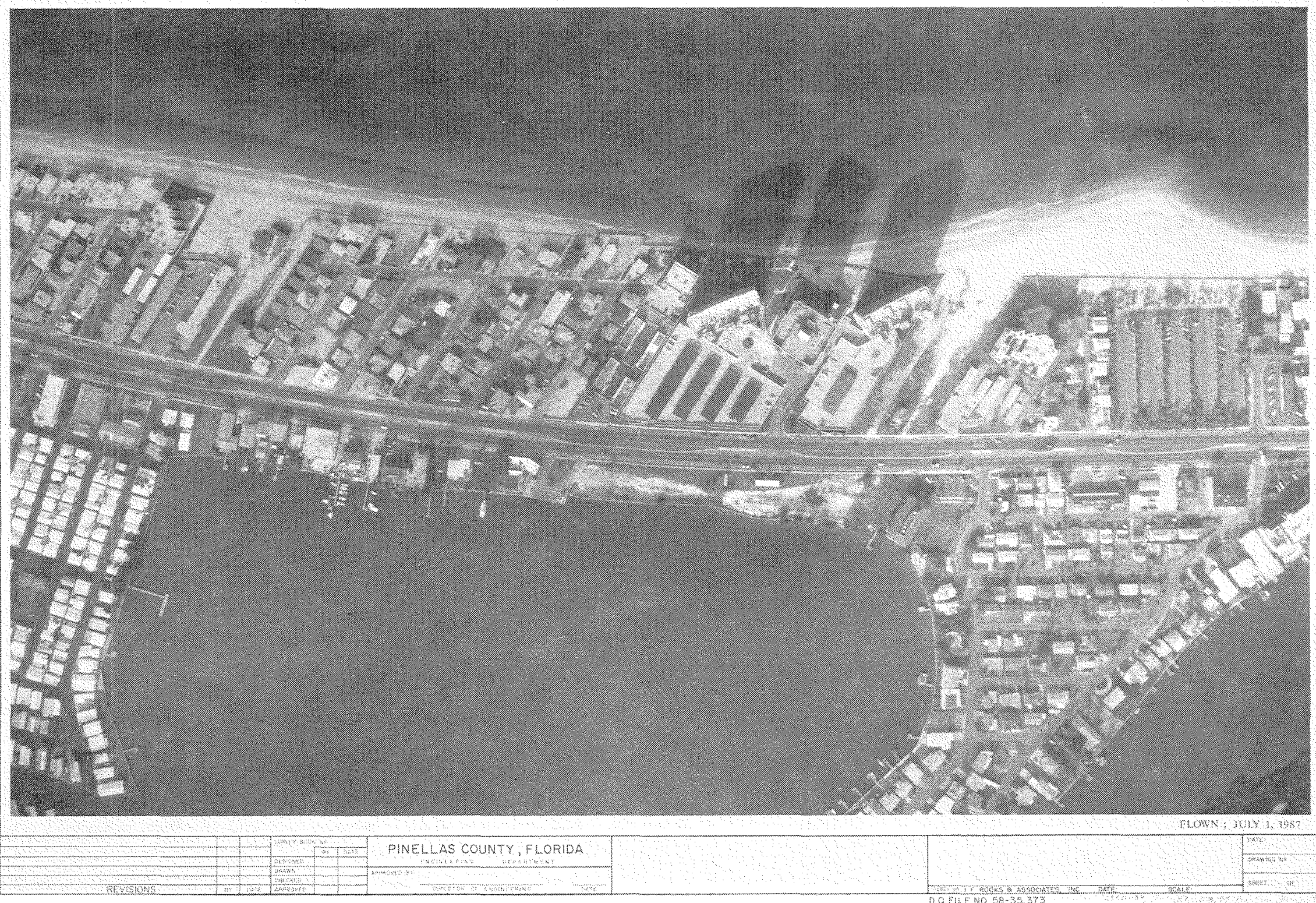

Figure Al. Aerial photography of Redington Shores, Florida breakwater, July 1987

(Sheet 1 of 2) 


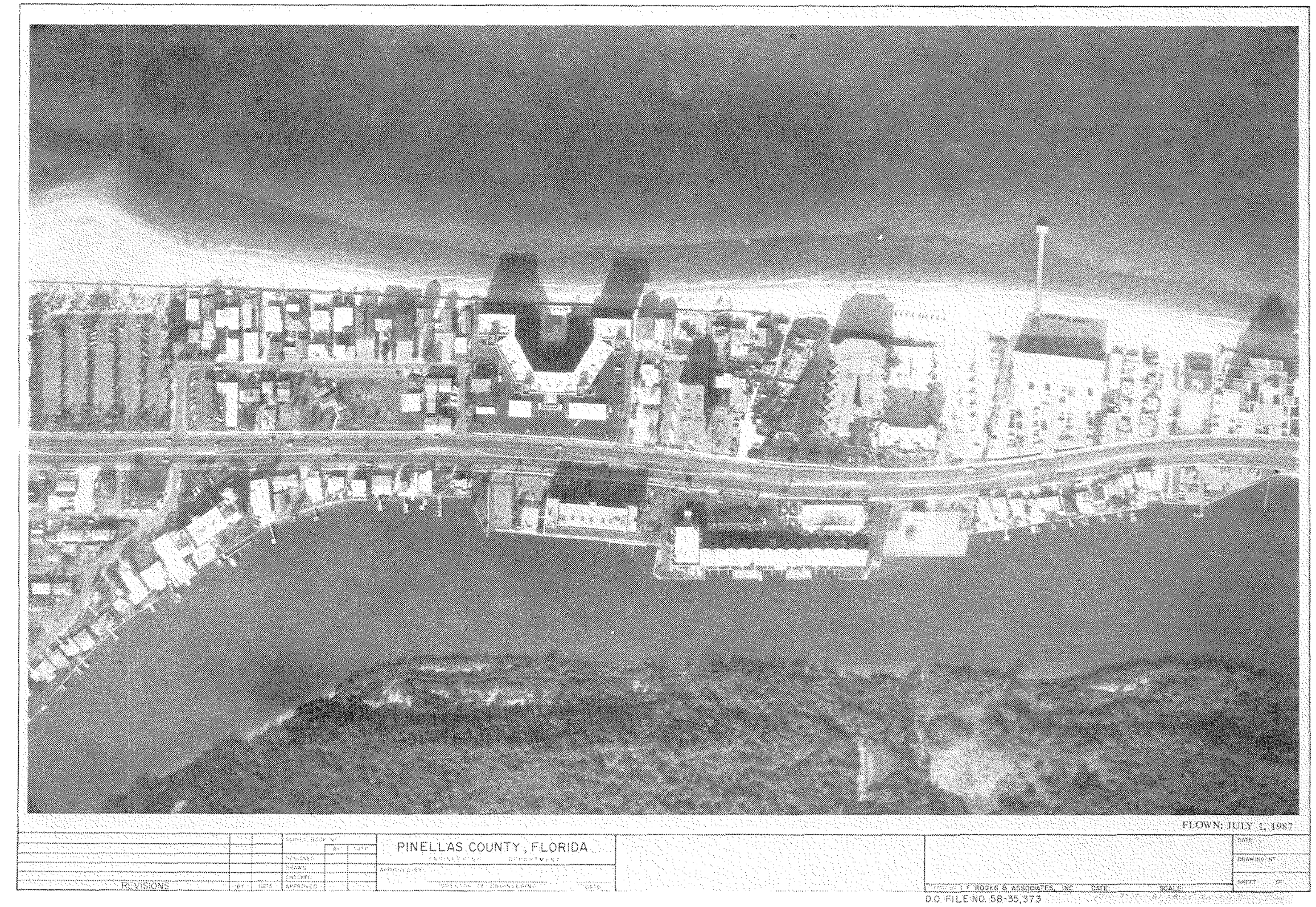

Figure Al. (Sheet 2 of 2) 


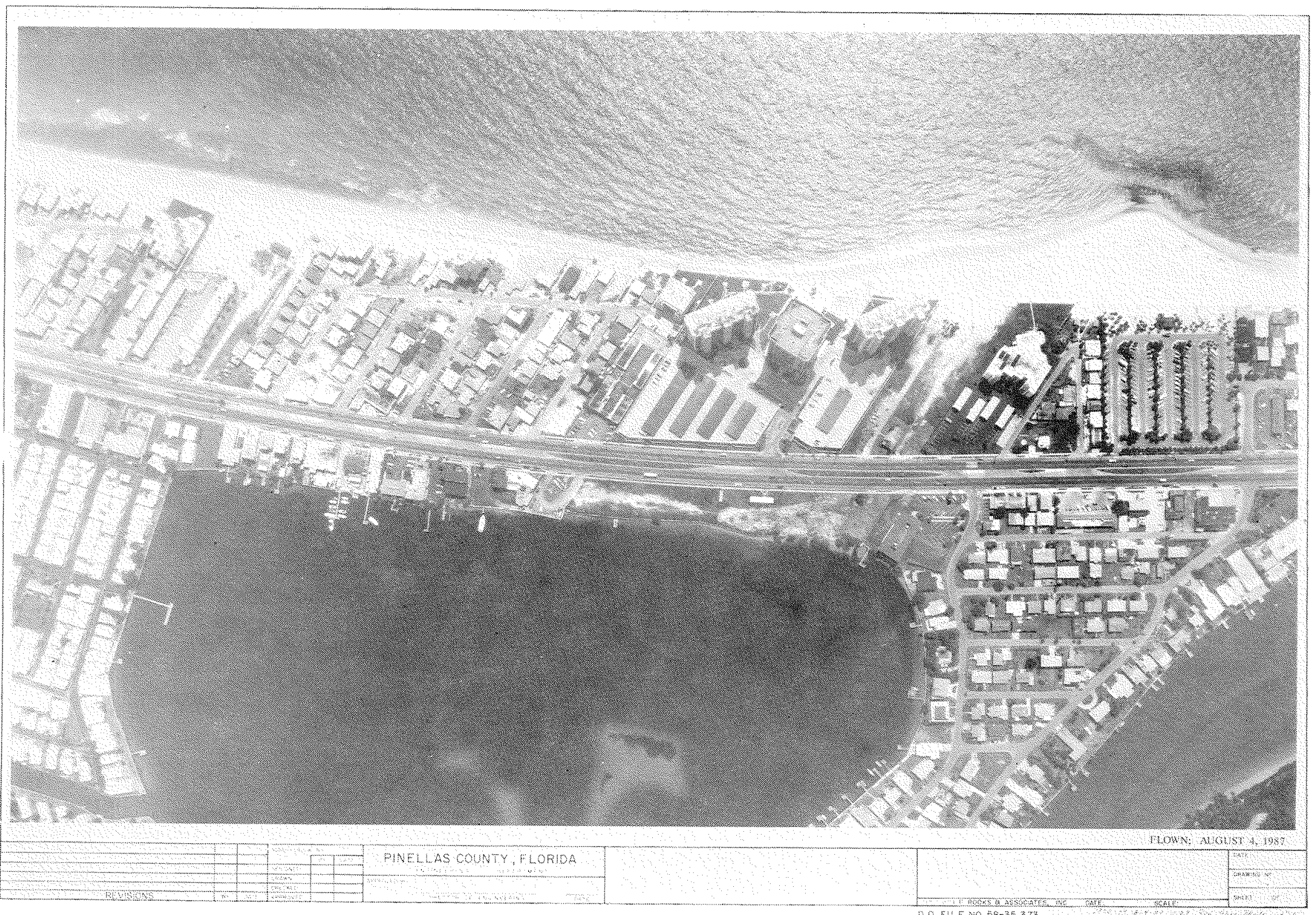

Figure A2. Aerial photography of Redington Shores, Florida breakwater, August 1987

(Sheet 1 of 2) 


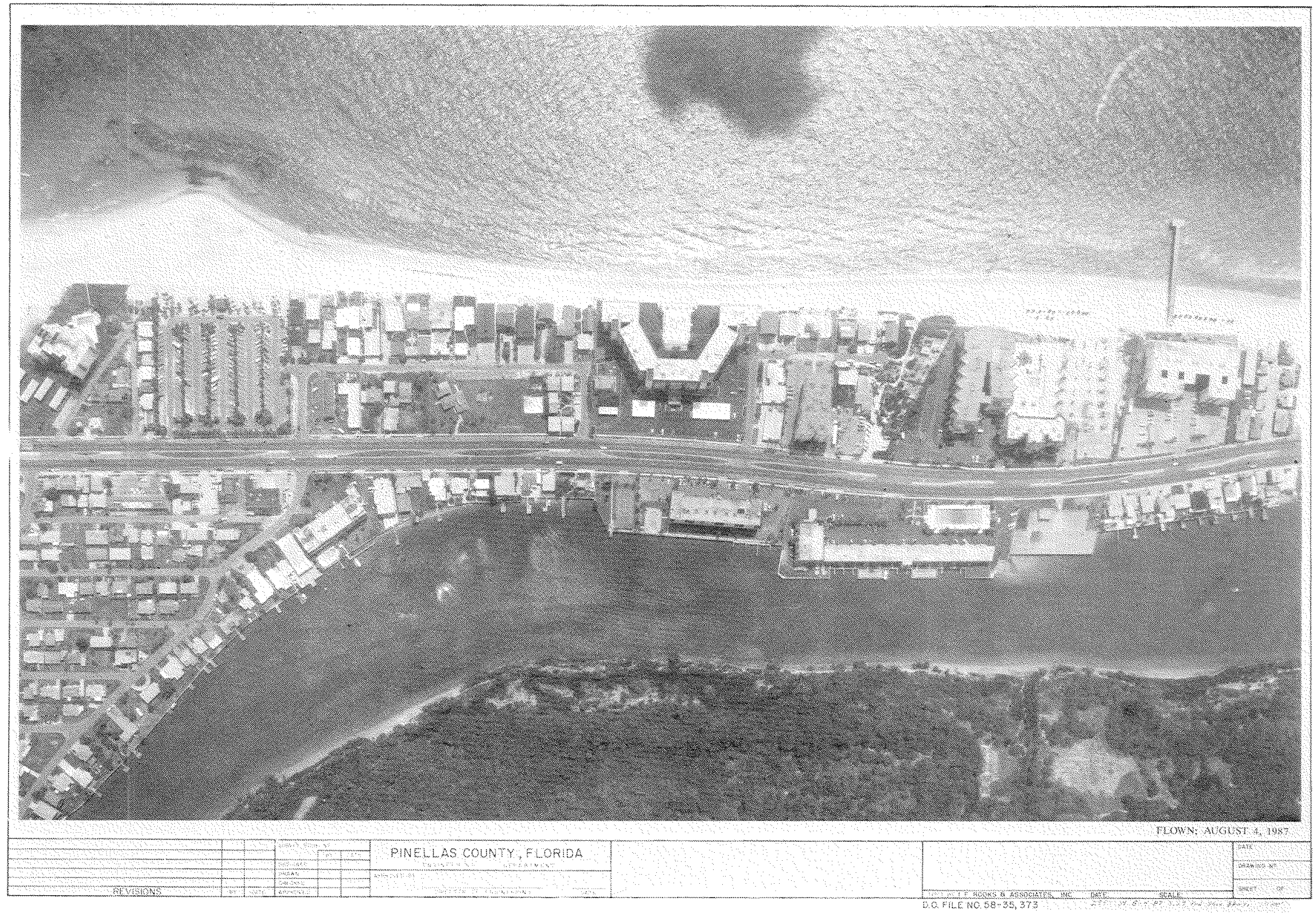

Figure A2. (Sheet 2 of 2) 


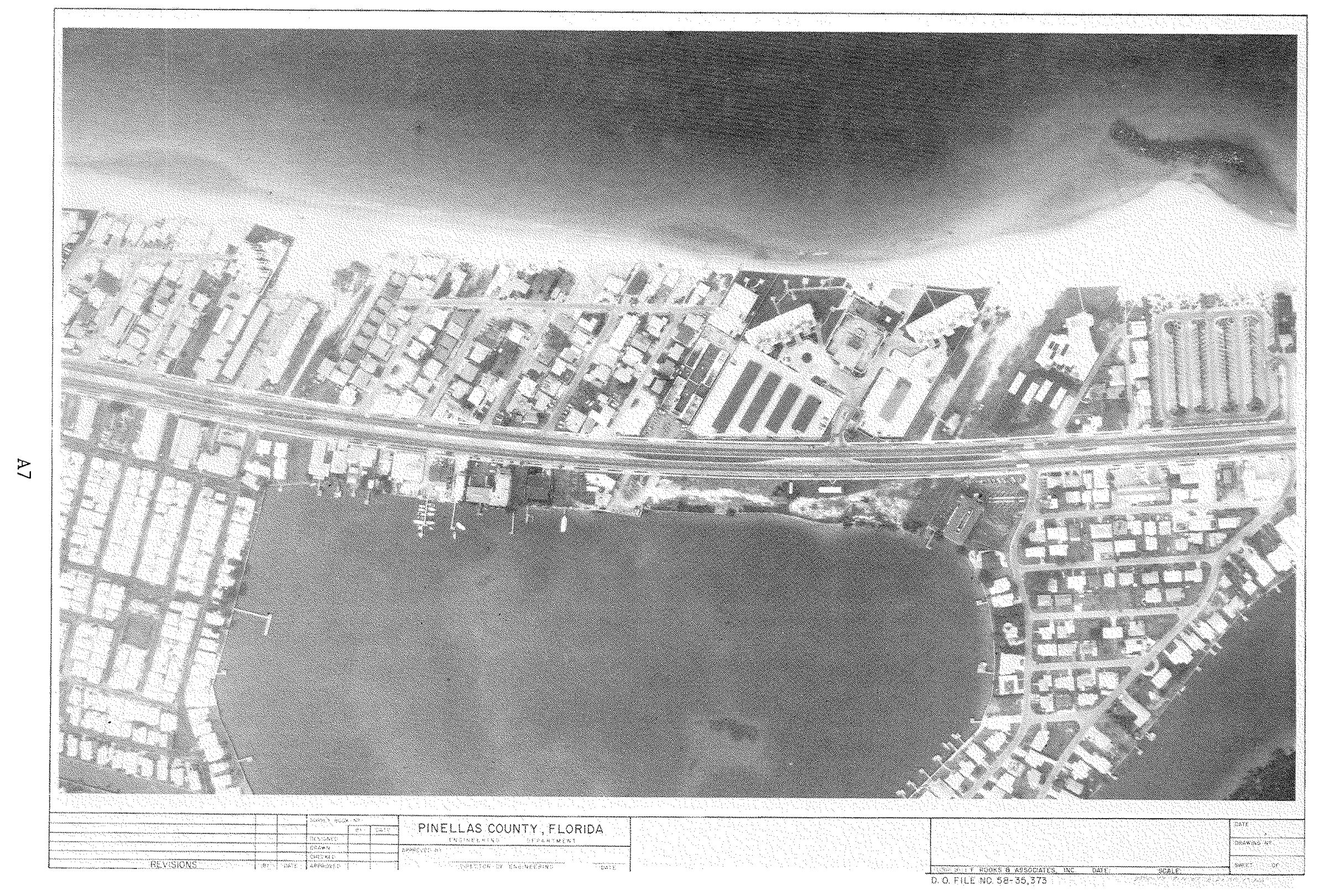

Figure A3. Aerial photography of Redington Shores, Florida breakwater, September 1987 (Sheet 1 of 2) 


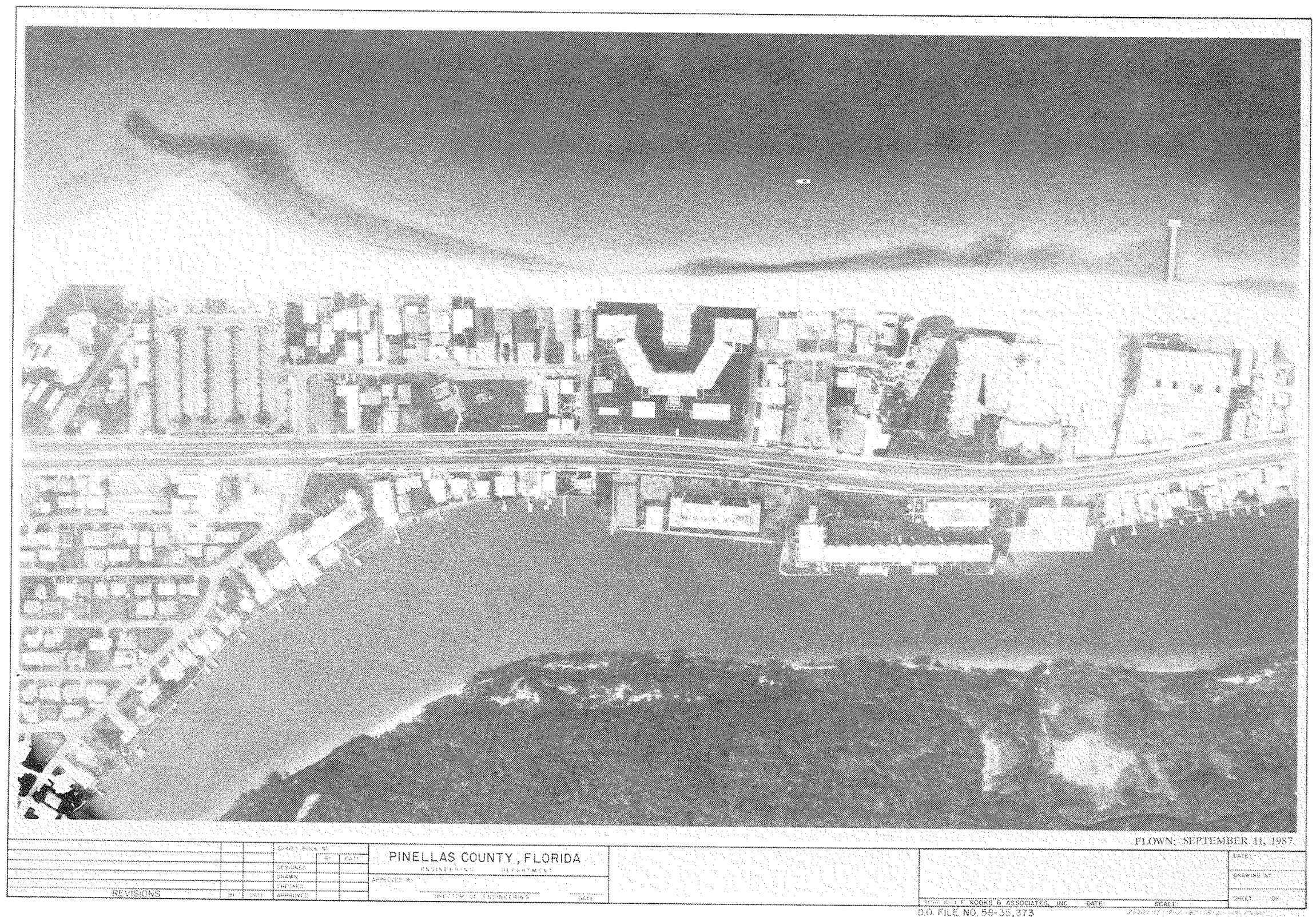

Figure A3. (Sheet 2 of 2) 


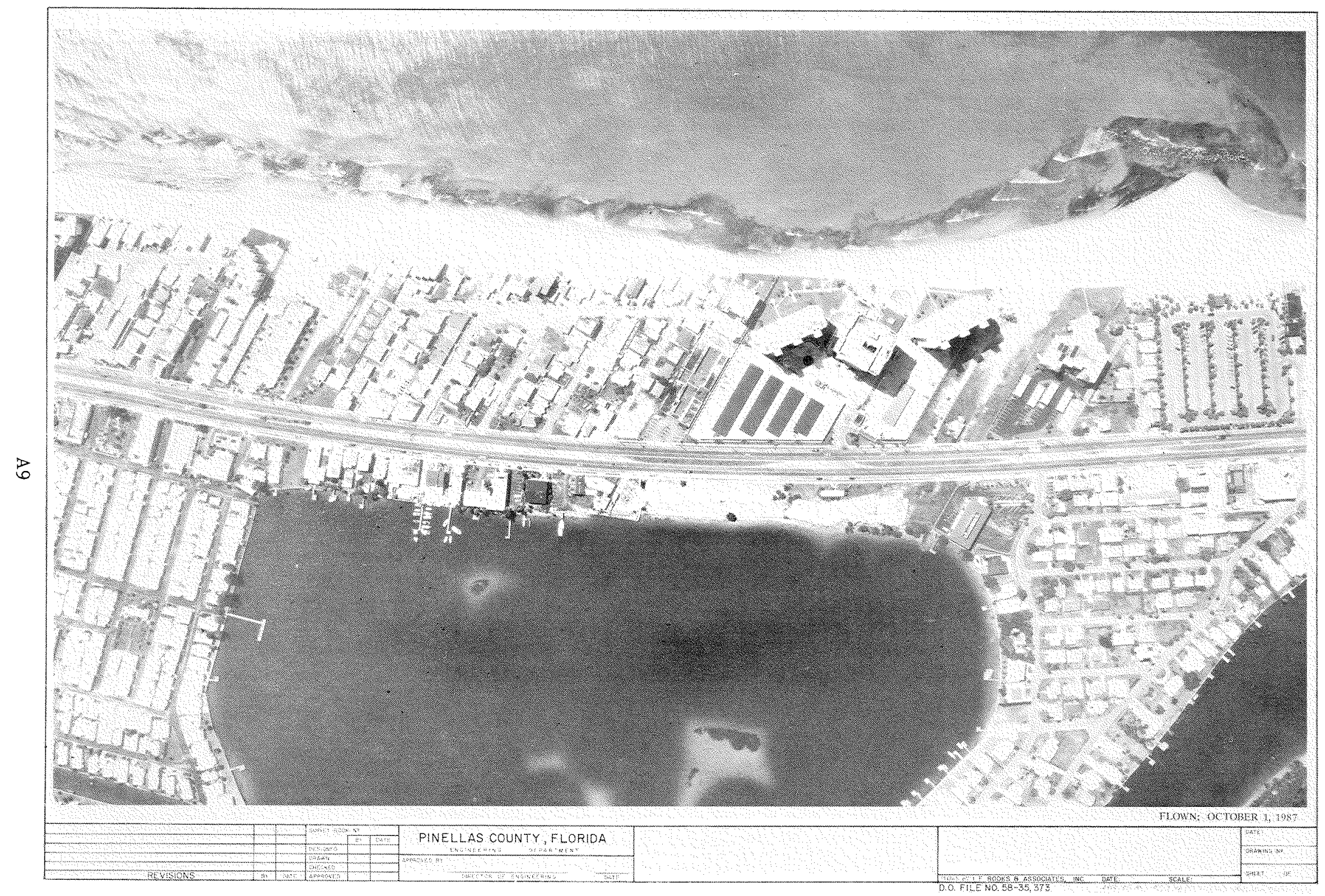

Figure A4. Aerial photography of Redington Shores, Florida breakwater, October 1987 (Sheet 1 of 2) 


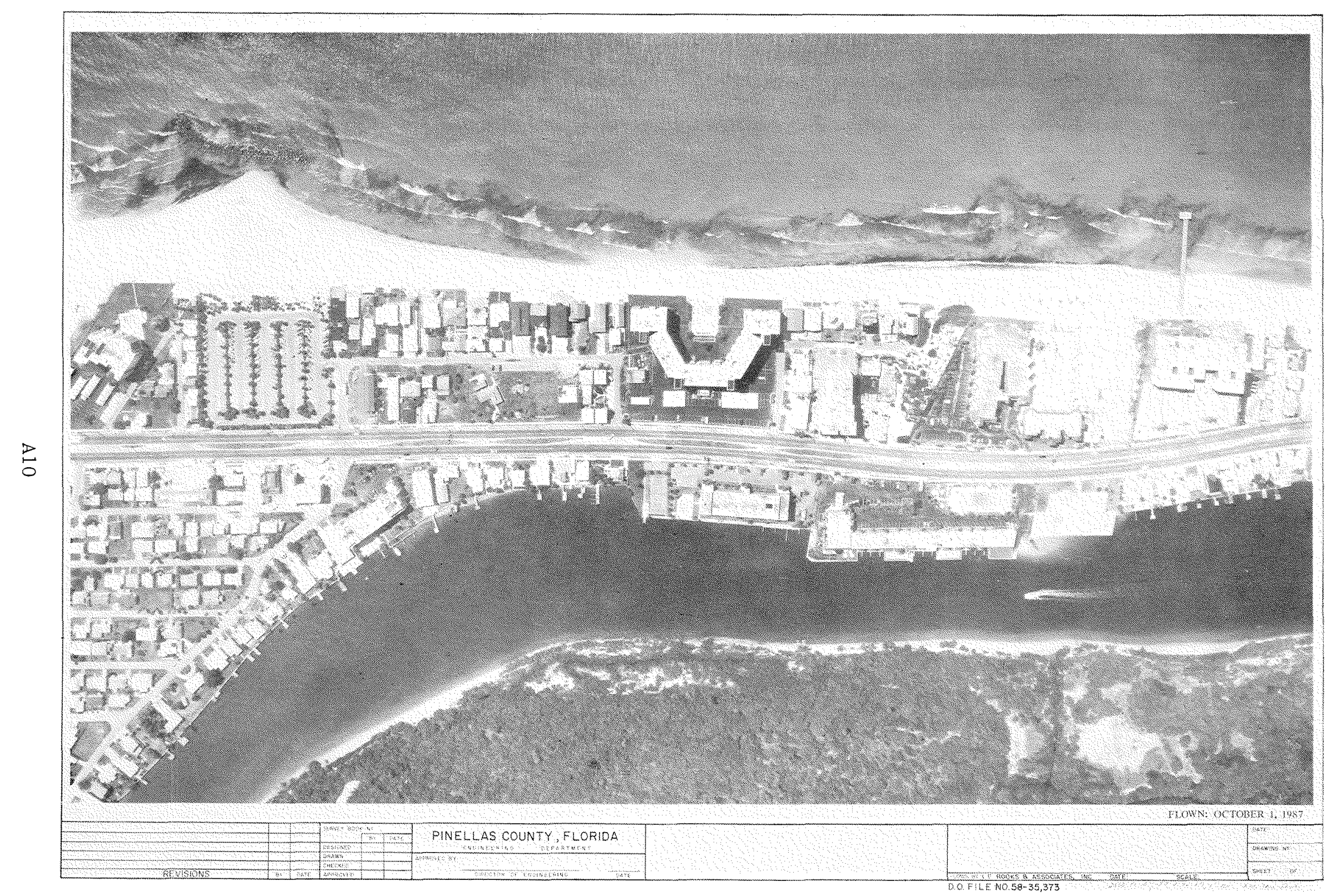

Figure A4. (Sheet 2 of 2) 


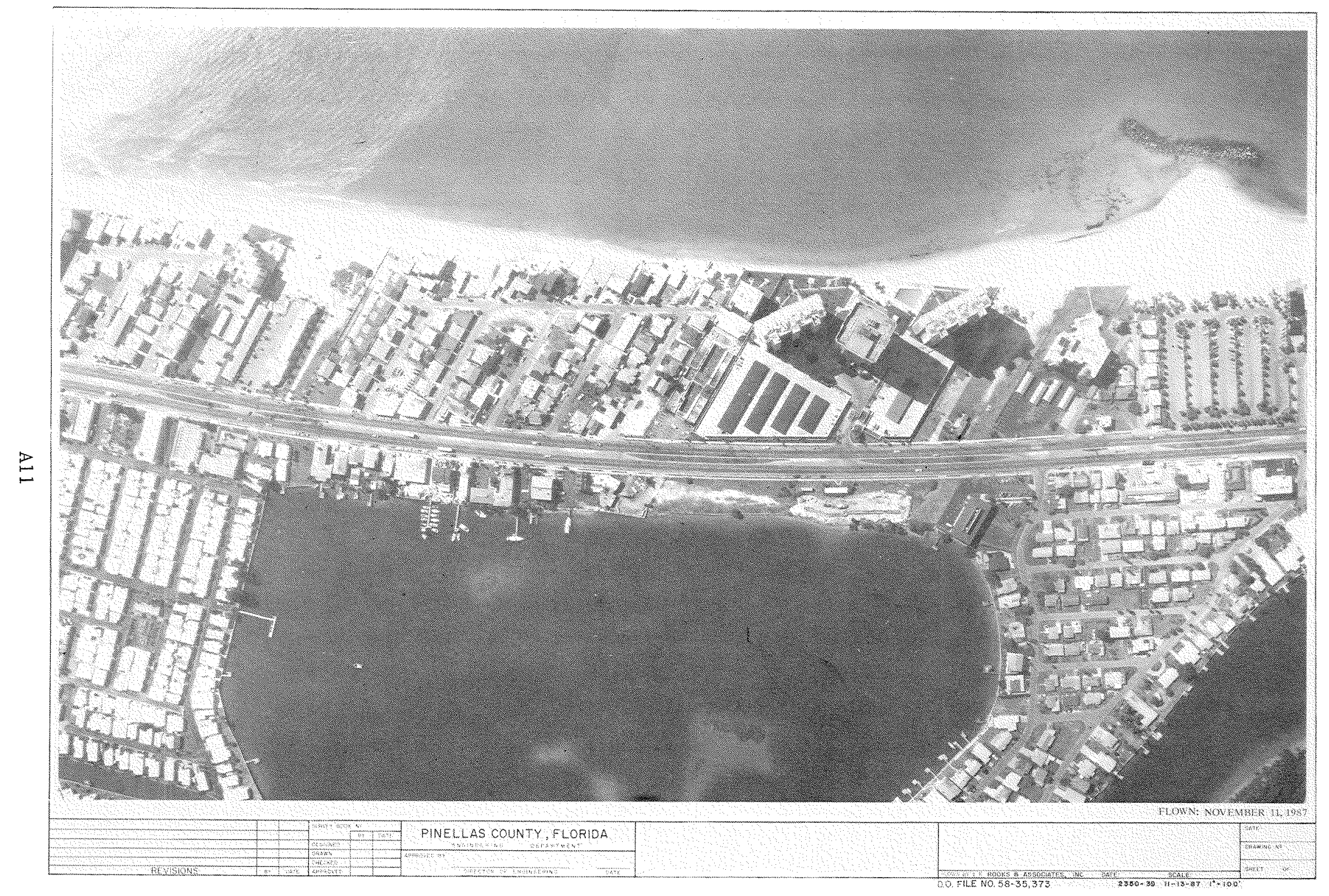

Figure A5. Aerial photography of Redington Shores, Florida breakwater, November 1987 (Sheet 1 of 2) 


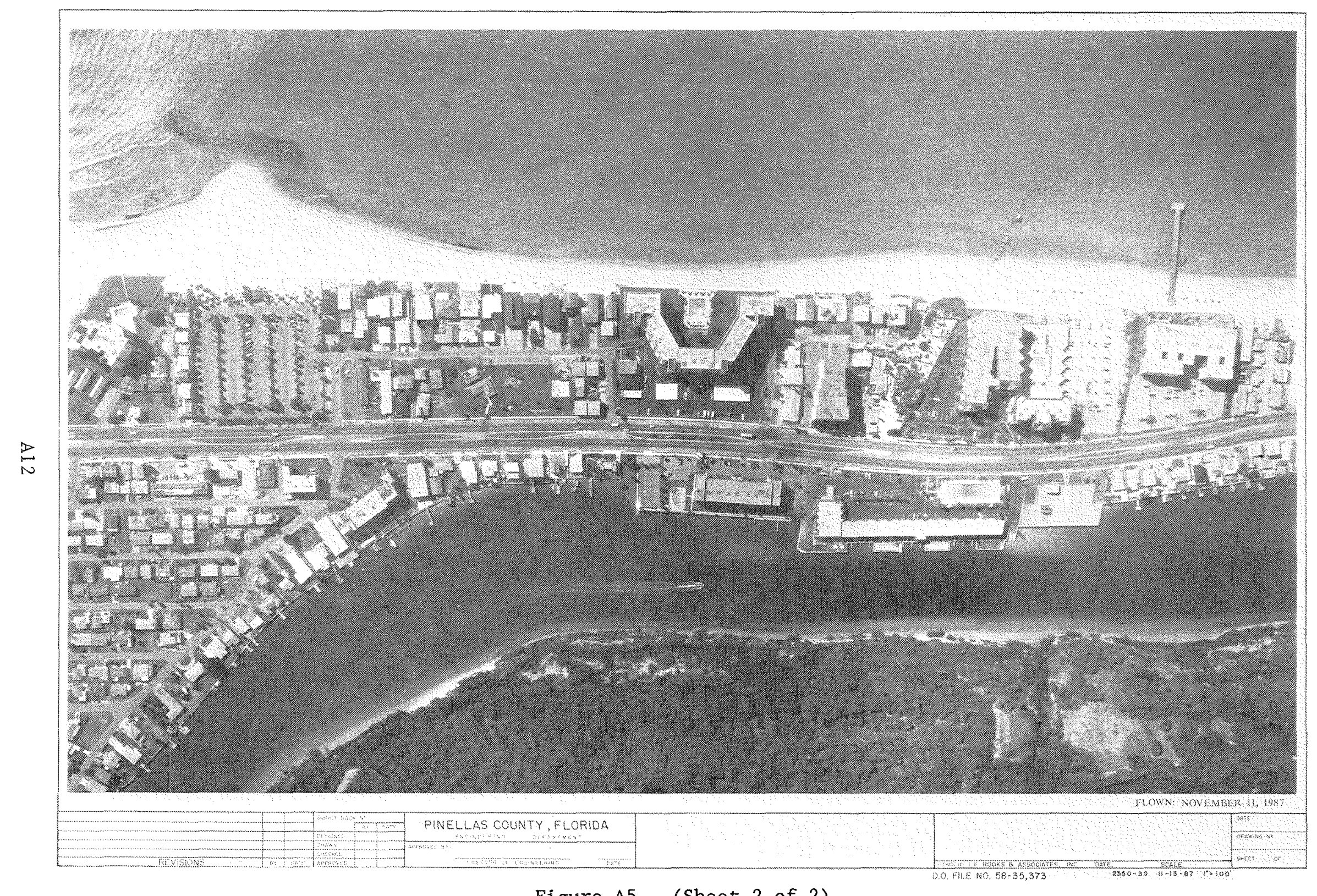

Figure A5. (Sheet 2 of 2) 


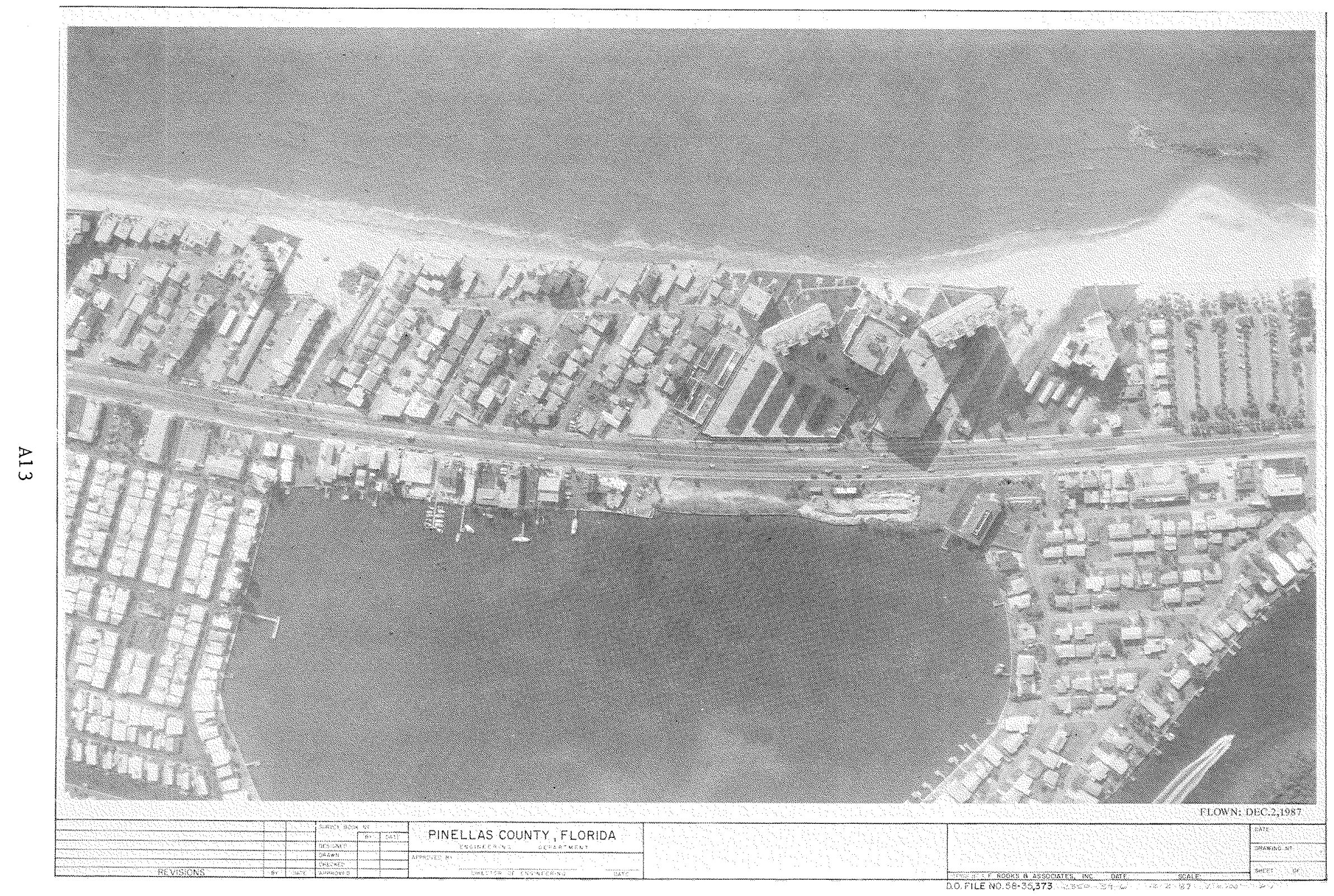

Figure A6. Aerial photography of Redington Shores, Florida breakwater, December 1987 (Sheet 1 of 2) 


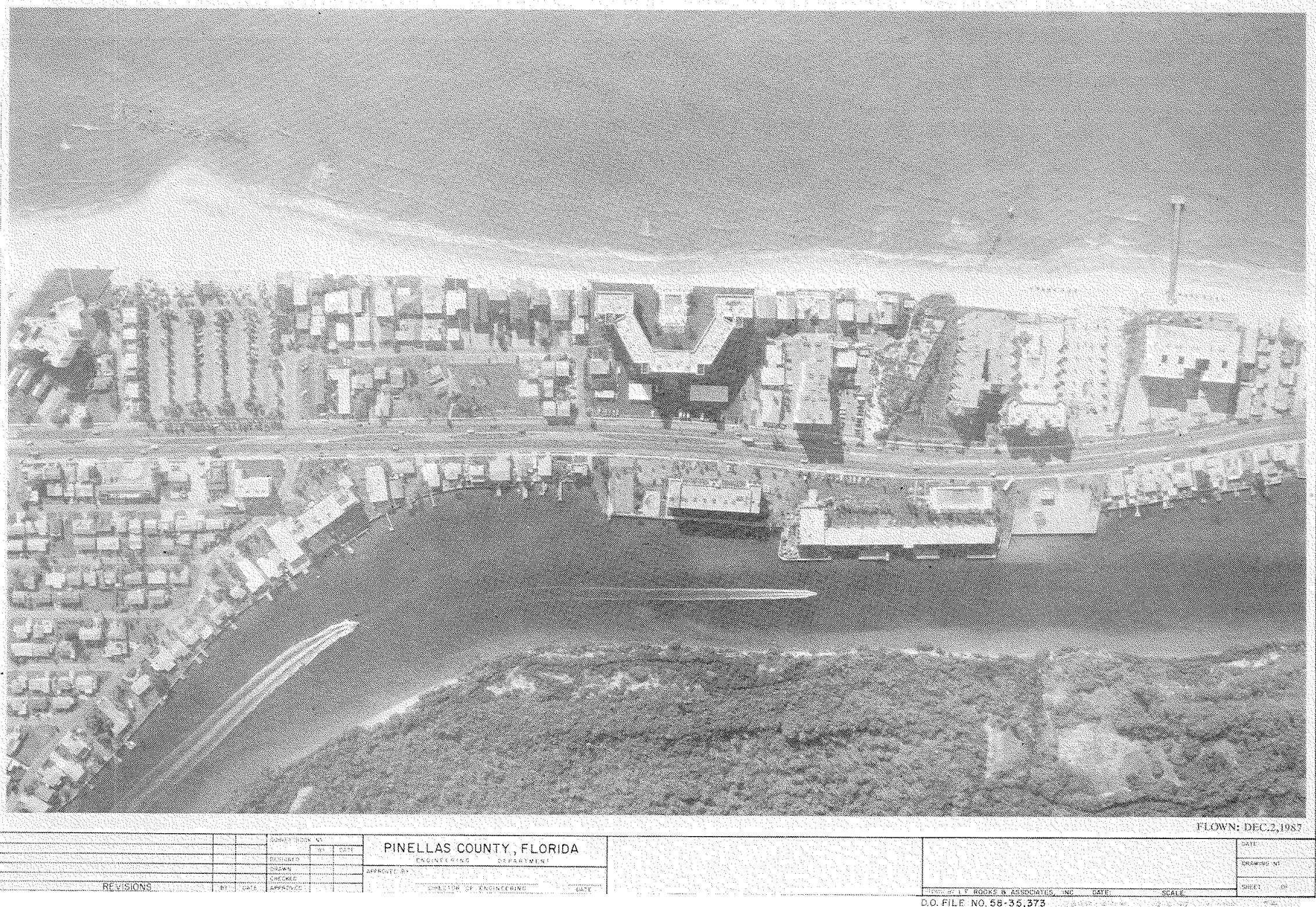

Figure A6. (Sheet 2 of 2) 


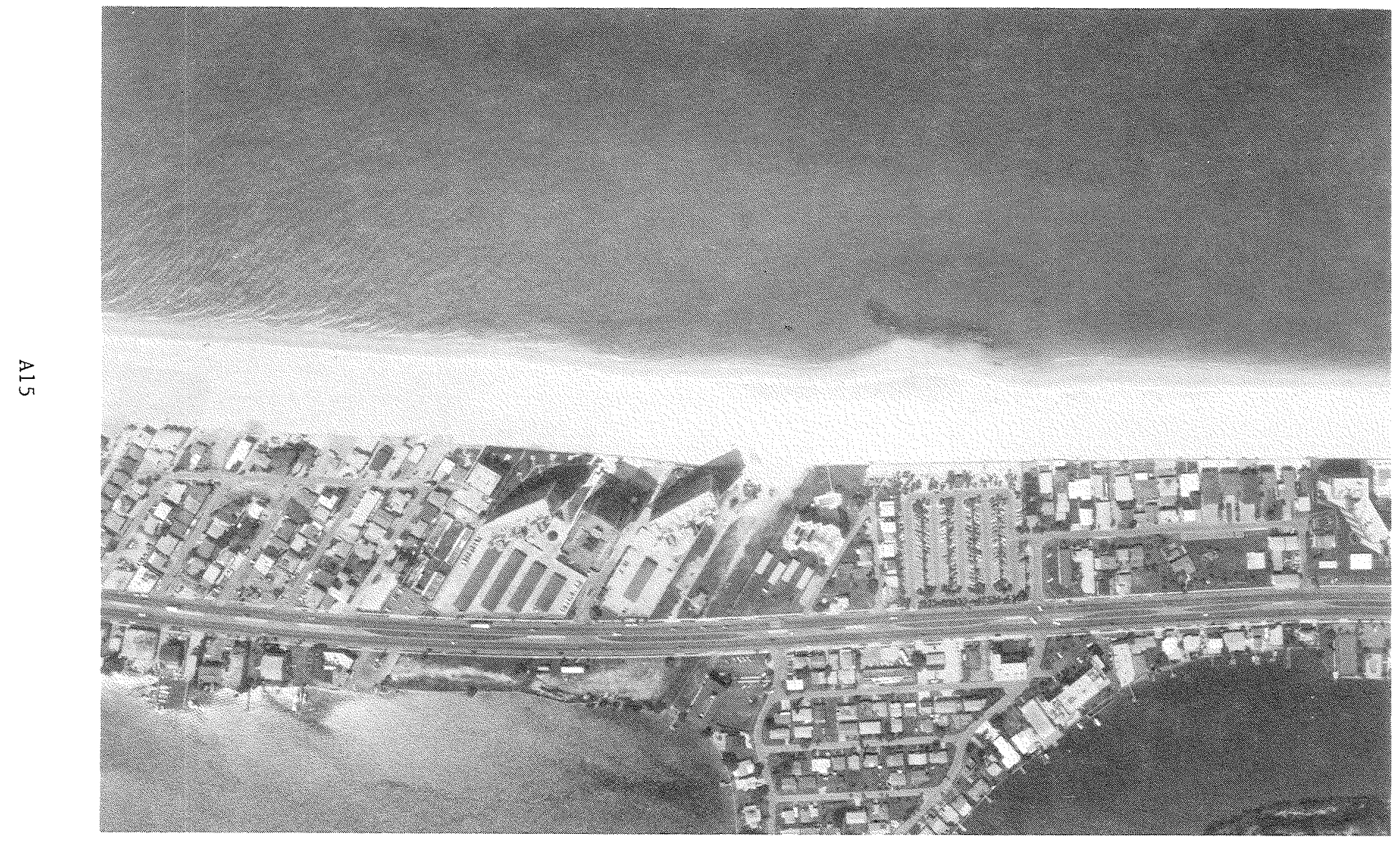

Figure A7. Redington Shores, Florida breakwater after modification and beach nourishment, September 1988 


\section{Waterways Experiment Station Cataloging-In-Publication Data}

Chu, Yen-hsi.

Beach response to the Redington Shores, Florida breakwater / by Yen-Hsi Chu, Coastal Engineering Research Center and Thomas Martin ; prepared for Department of the Army, U.S. Army Corps of Engineers.

47 p. : ill. ; $28 \mathrm{~cm}$. - (Miscellaneous paper ; CERC-92-8) Includes bibliographic references.

1. Breakwaters - Florida - Pinellas County - Evaluation. 2. Shore protection - Florida - Pinellas County. I. Martin, Thomas. II. United States. Army. Corps of Engineers. III. Coastal Engineering Research Center (U.S.) IV. U.S. Army Engineer Waterways Experiment Station. V. Title. VI. Series: Miscellaneous paper (U.S. Army Engineer Waterways Experiment Station); CERC-92-8.

TA7 W34m no.CERC-92-8 